\title{
Os guardados da viscondessa: fotografia e memória na coleção Ribeiro de Avellar
}

Mariana de Aguiar Ferreira Muaze ${ }^{2}$

RESUMO: O presente trabalho discute o tema da família no Império através do viés metodológico da micro-história e da análise da documentação íntima que pertenceu à família Ribeiro de Avellar, rica proprietária de terras, cafezais e escravos em Paty do Alferes, Vale do Paraíba fluminense. A análise dos retratos fotográficos foi privilegiada, no intuito de refletir sobre os diferentes tipos de circulação das imagens e o ideal de família vigente.

PALAVRAS-CHAVE: História de família. Micro-história. Fotografia. Retrato. Família Ribeiro de Avellar. Vale do Paraíba.

ABSTRACT: This paper discusses the theme of family life when Brazil was an empire, using the methodological approach of microhistory and by analyzing personal documents that belonged to the Ribeiro de Avellar family, who were wealthy landowners and proprietors of coffee plantations and slaves in Paty do Alferes, located in the Paraíba River Valley of the Province of Rio de Janeiro. The author focused on the analysis of photographic portraits in order to reflect upon the different means of circulation of images and the prevailing family ideal at the time.

KEYWORDS: Family history. Microhistory. Photography. Portraiture. Ribeiro de Avellar. Vale do Paraíba.

A série documental analisada pertenceu a Marianna Velho de Avellar, viscondessa de Ubá, e foi composta ao longo de mais de quarenta anos de vida conjugal e mesmo após a morte do marido Joaquim Ribeiro de Avellar Jr., visconde de Ubá, filho do barão de Capivary. A união matrimonial de ambos foi arranjada para atender aos interesses da família Velho da Silva, há muito estabelecida na burocracia de Corte, e dos Ribeiro de Avellar, proprietários da Fazenda Pau Grande e tradicionais senhores de terras e escravos na região cafeeira do Vale do Paraíba fluminense ${ }^{3}$. Desta forma, pode-se inferir que a história desta coleção se confunde com a própria história de vida da viscondessa. As primeiras cartas, documentos e fotografias armazenados são da década de
1. Este artigo apresenta as principais reflexões contidas na terceira parte de minha tese de doutoramento: O Império do Retrato: família, riqueza e representação social no Brasil oitocentista (18401889). Tese (Doutorado em História)-Faculdade de História, Universidade Federal Fluminense, Niterói, 2006.

2. Doutora pela Universidade Federal Fluminense/RJ. E-mail: <mamuaze @ click21.com.br> ou <mamuaze@ig.com.br>.

3.MariannaVelho deAvellar era a primogênita de José Maria Velho da Silva, mordomo do Paço, e Leonarda Maria Velho da Silva, dama da Imperatriz Theresa Cristina. Tendo enriquecido com o tráfico internacional de almas, os Velho da Silva serviram a Família Imperial desde a chegada de $\mathrm{D}$. João VI ao Brasil, configurando-se em uma das famílias mais tradicionais na burocracia da Corte. Em 1849, Marianna casou-se com Joaquim Ribeiro de Avellar Jr.A família Ribeiro de Avellar era proveniente de ricos comerciantes portugueses, estabelecidos na praça 
do Rio de Janeiro, que haviam participado da colonização do Vale do Paraíba fluminense, desde o século XVIII, tendo assim adquirido a sesmaria do Pau Grande. Na primeira década do oitocentos, migraram definitivamente para a região, em busca de maior prestígio social com a compra de escravos, o plantio de açúcar e, posteriormente, de café.

\begin{abstract}
4. Patenteado em 1854 por Eugène Disdéri, a nova invenção utilizava quatro lentes objetivas em uma única câmera fotográfica produzindo, assim, quatro imagens reduzidas de uma só vez. As fotos, no tamanho $6 \times 9,5$ $\mathrm{cm}$, eram coladas sobre cartão. Tal inovação foi responsável pelo barateamento do retrato fotográfico.
\end{abstract}

5.A documentação utilizada nesta pesquisa fazia parte de uma mesma coleção familiar, composta por álbuns, cartas, recibos, documentos cartoriais, etc. Entretanto, atualmente, parte dela foi doada ao Arquivo Nacional, pelo atual dono da $\mathrm{Fa}$ zenda do Pau Grande, outra parte se encontra nas mãos de herdeiros e colecionadores que não me autorizaram a citar seus nomes neste trabalho. Por isso, vou referir-me às suas coleções da seguinte forma: Coleção Roberto Menezes de Moraes (fotografias avulso), Coleção Particular 1 (três ál buns de fotografias e documentos) e Coleção Particular 2 (quatro séries epistolares). Desde já, agradeço a generosidade e carinho deles, que me abriram suas casas e pertences para que eu realizasse esta pesquisa.
1850, logo após o seu casamento, e avolumaram-se bastante a partir de 1853, quando deixou a capital e passou a residir na fazenda Pau Grande, juntamente com o marido e filhos, tendo que assumir o governo da casa e o controle da esfera doméstica.

Os motivos que levaram a mudança dos recém-casados para a província foram muitos: estado de saúde do sogro, herança recebida pelo marido, necessidade de estar à frente dos negócios da fazenda e aumento da prole. No entanto, é interessante ressaltar que a distância fomentou o desejo de corresponderem-se com seus entes queridos, numa tentativa de manter e confirmar laços de amizade e afetividade, através do envio de cartas e fotografias àqueles que haviam deixado na Corte. Com este intuito, Marianna Velho de Avellar trocou semanalmente correspondências, por mais de quinze anos, com seus pais - Leonarda e José Maria Velho da Silva - até a morte dos progenitores. Esta série epistolar descrita, juntamente com outros registros pertencentes à coleção, demonstra sua preocupação de que os laços de solidariedade fossem mantidos e estendidos no interior da parentela, ampliada com a aliança matrimonial. Tal afirmação pode ser comprovada não só pela recorrência da troca e circulação de cartes de visite ${ }^{4}$ entre os novos e velhos parentes, mas também pela forma com que os agentes históricos se relacionavam nas cartas; sempre preocupados em reafirmar a prática das recomendações e e expressão de sentimentalidades:

\footnotetext{
Minha querida filha Marianinha, $[\ldots]$ muitos abraços e beijos.

[...] Aceita um saudoso abraço de

Teu pai amado do coração.

Velho ${ }^{5}$.
}

Te peço que me recomende muito ao Sr. Barão, agradecendo-the por mim tantos obséquios que me fez e também a vovó Tonha, tia Annica, tia Maria moça e tia velha, a José Mascarenhas e Joaquim e ao Boaventura. As nossas caras meninas

A coleção da viscondessa reuniu não só a sua própria documentação íntima, mas também incorporava as de outros familiares, recuperadas após os falecimentos dos mesmos. No conjunto encontram-se fotografias dedicadas a terceiros, cartas particulares do sogro recebidas de seu comissário de café Domingos Alves da Silva Porto, amigos e parentes; além de correspondências suas remetidas aos pais, ao filho José Maria e ao irmão. Tal aspecto demonstra uma preocupação, consciente ou inconsciente, de resguardar pertences pessoais de familiares falecidos, com o intuito de impedir que a própria memória do grupo familiar fosse perdida. Portanto, a forma com que, pessoalmente, Mariana arquitetou e construiu sua coleção demonstra uma intenção em manter reunidos diferentes registros que se entrelaçam pelo fio do tempo familiar.

Durante toda sua vida de casada, juntamente com outras funções femininas, a sra. Velho de Avellar desempenhou com maestria o papel de guardiã de uma dada memória familiar para a sua geração e para as futuras, produzindo, selecionando, organizando e investindo afeto em cartas, retratos, livros de 
assento, bilhetes e cadernos de anotações. A multiplicidade de documentos reunidos pela viscondessa visava a produzir uma memória que ressaltasse as diversas temporalidades familiares, seus personagens, sentimentalidades e seu lugar de destaque na sociedade imperial. Assim, acumulou documentos que se tornam monumentos ${ }^{6}$, na medida em que revelam valores e comportamentos que possibilitam recuperar não só um habitus ${ }^{7}$ de grupo ${ }^{8}$, mas também as formas de representação social que atuaram como elemento de coesão interna (no âmbito da família e da parentela) e externa (no seio da classe senhorial à qual pertencia)

Estes "guardados familiares", sem dúvida, sofriam um processo de seleção e descarte, cujos critérios eram estabelecidos pela própria Marianna. Algumas cartas, por exemplo, vinham com um alerta escrito acima, no canto esquerdo da página: "reservada". Em outras, acrescentava-se a ordem para que fosse queimada após a leitura ${ }^{10}$. Contudo, se aqui posso relatar esse pedido confiado intimamente ao destinatário, é porque ele não foi respeitado. Nesse caso, a ânsia de guardar e colecionar deixou indícios que me permitem historiar. $\bigcirc$ mesmo ocorria com os retratos, escolhidos em meio a uma gama de possibilidades e organizados em álbuns que eram dispostos na sala de estar da casa-grande. Do imenso conjunto, restaram 231 fotografias de parentes e amigos, distribuídas em três álbuns, e 69 imagens avulsas.

Minha proposta neste artigo é analisar esta série fotográfica, entendendo-a como parte de uma coleção familiar que tem sua história própria e que, portanto, não pode ser desvinculada da mesma ". Dessa forma, por um lado, os registros visuais e escritos se relacionam no que diz respeito à sua própria sobrevivência no tempo e no espaço, possibilitada pela viscondessa em seu intuito de colecionar. Por outro lado, a fotografia - entendida como uma representação do real composta por signos convencionados e compartilhados culturalmente - requer a interpretação "de outros textos que a precedem, ou que com ela concorrem, para a produção da textualidade de uma época", no sentido de levantar a cultura histórica institucionalizadora dos códigos de representação que conformaram as imagens fotográficas ${ }^{12}$. Novamente, faz-se necessária uma interpretação que ressalte o diálogo entre as fotografias e as cartas de família presentes na coleção. Ou seja, uma reflexão que procure perceber o que esses diferentes discursos têm a dizer sobre a cultura e o habitus das famílias da classe senhorial oitocentista.

A análise da série fotográfica pertencente à coleção Ribeiro de Avellar orienta-se por quatro hipóteses centrais, que serão discutidas mais detalhadamente ao longo do texto:

1. Apesar de o retrato fotográfico estar relacionado à construção de uma dimensão individual, isso não significou - em frações importantes da classe senhorial à qual o visconde e a viscondessa de Ubá pertenciam - o abandono da noção da família extensa.

2. Dentre os retratos familiares estudados, percebem-se duas esferas de circulação distintas. Os produzidos pelo fotógrafo itinerante Manoel de Paula Ramos, na própria Fazenda Pau Grande, ficavam circunscritos ao círculo dos parentes mais próximos. Já os tirados em estúdios por fotógrafos
6. Ver Jacques Le Goff (1985).

7. O conceito de habitus utilizado nesta análise se pauta naquele construído por Norbert Elias (ELIAS, 1993; 1994a; 1994b; 1995); (ELIAS; SCOTSON, 1994).

8. Ver Jacques Le Goff (1985).

9. Ver Ana Maria Mauad (1995).

10. Carta de D. Leonarda Velho da Silva para Marianna Velho de Avellar. Rio de Janeiro, 30 de março de 1867 (Coleção Particular 2).

11.Ver Vânia Carneiro de Carvalho e Solange Ferraz de Lima (2000).

12. Cf. Ana Maria Mauad (1996). 
de renome, cujo custo e produção eram mais elevados, alcançavam um espectro maior. Seus cartes de visite eram enviados, inclusive para fora do Brasil, como recordação a parentes, amigos e futuros pretendentes, como forma de consolidar e estabelecer laços de amizade e fidelidade.

3. Dentre os indivíduos retratados, os jovens e os adultos são os mais numerosos na coleção, tendo recebido maior investimento de capital simbólico. Já as imagens de idosos e crianças permaneceram restritas às pessoas mais íntimas ao círculo familiar.

4. Se na Europa a invenção e a disseminação da fotografia estiveram, por excelência, ligadas à ascensão da sociedade burguesa e à consolidação de um modelo econômico capitalista, no Brasil essa realidade não se verificou. $\bigcirc$ modo de vida burguês foi reinterpretado, tendo as práticas de consumo como organizadoras das representações sociais, que as transformações técnicas e a planificação do trabalho preencheram nos países centrais do sistema capitalista. Portanto, pode-se dizer que o Império procurou compartilhar da civilização da imagem sem se despojar de um modelo escravista e agrário-exportador.

Narrativa visual: o triunfo da família oitocentista

A fotografia foi, sem dúvida, uma forma privilegiada de representação da sociedade oitocentista. Suas principais expressões eram as imagens de vistas e os retratos, que delinearam um amplo circuito social da fotografia na Corte do Rio de Janeiro durante a segunda metade do século XIX ${ }^{13}$. Enquanto as primeiras tinham ampla aceitação nas exposições universais, inebriando os olhos curiosos de europeus e estabelecendo-se como uma importante forma de representação da única monarquia nos trópicos ${ }^{14}$, os retratos fotográficos preenchiam os álbuns de família, cada vez mais em moda a partir dos anos 1850, e circulavam amplamente, ao serem trocados entre parentes e amigos, enviados dentro de cartas para destinatários distantes ou remetidos com fins de apresentação. Os Ribeiro de Avellar compartilharam com desenvoltura dessa civilização da imagem e da ambiência cultural por ela requerida, no sentido de dominarem seus códigos de produção, consumo, circulação, leitura e ação social ${ }^{15}$. A série da Viscondessa, composta por 231 retratos fotográficos, comprova esta hipótese não só por sua extensão numérica e grande distribuição, mas também pela diversidade de indivíduos retratados.

Historicamente, desde sua invenção, o retrato fotográfico esteve ligado a uma dimensão individual necessária ao homem moderno, para reforçar uma identidade singular numa sociedade em constante transformação. Não parece à toa ter sido o retrato individualizado a sua versão mais difundida no século XIX, principalmente depois do surgimento do carte de visite, que barateou os custos da fotografia através da produção de quatro a oito imagens de uma só vez.

$\bigcirc$ ato de posar diante da objetiva de um fotógrafo estabelecia uma negociação entre retratista e retratado. A escolha da pose a ser perenizada era, 
portanto, realizada por esses dois sujeitos envolvidos na cena fotográfica. Ao primeiro cabia o conhecimento técnico: busca do melhor ângulo, iluminação, enquadramento, foco, nitidez e harmonização dos planos, segundo padrões estéticos ainda ligados às artes plásticas. Já o cliente, este deveria livrar-se de todas as preocupações cotidianas e concentrar-se naquele momento único. Os objetos do cenário e os fundos fornecidos pelo estúdio eram escolhidos de modo a criar a atmosfera desejada. A indumentária, em geral, pertencia àquele que contratava os serviços. Tudo pronto, era chegada a hora da pose! $\bigcirc$ gesto, a expressão facial, a direção do olhar, assim como os objetos pessoais e os penteados eram calculados para produzirem uma imagem condizente com os símbolos da classe com a qual gostaria de ser identificado ${ }^{16}$.

Portanto, posar diante da câmera era um ato de "invenção de si", no qual biografado (retratado) e biógrafo (retratista) usavam seus atributos a fim de transformar em realidade revelada sobre o papel emulsionado o tipo de representação social desejada. Dessa forma, o indivíduo era colocado em destaque apresentando-se como o principal personagem no espaço da figuração da foto ${ }^{17}$. Na coleção analisada, $78 \%$ dos retratos são imagens individuais, e somente $22 \%$ das imagens foram compostas por duas ou mais pessoas. Dentre os sujeitos retratados individualmente, 44\% eram adultos homens, $41 \%$ adultos mulheres e $15 \%$ crianças. No caso das fotografias masculinas, a preferência era pelo enquadramento de busto (71\%), que valorizava ainda mais o sujeito, através da aproximação da objetiva. Para as mulheres e as crianças, a fotografia de corpo inteiro superou de longe todos os outros recortes. Em ambos os casos, há o predomínio da representação individualizada no espaço da figuração do retrato oitocentista.

Contudo, se por um lado, pode se inferir que havia uma ênfase do indivíduo no retrato fotográfico - não só no espaço da figuração da foto, mas também como seu principal produtor e consumidor -, a análise serial das imagens e a disposição em que elas foram organizadas nas páginas dos imponentes álbuns de retratos da viscondessa demonstram uma narrativa visual conduzida através do fio da família extensa. A escolha, colocação e organização das imagens nos álbuns constituía um ato de construção de memória, onde uma determinada pessoa ou grupo - no caso aqui apresentado, Marianna Velho de Avellar - determinava o que seria ou não preservado da ação do esquecimento. Sua escolha, feita no quadro das múltiplas escolhas possíveis, foi um ordenamento que inserisse os indivíduos no seu grupo familiar, disponibilizando lado a lado, nas mesmas páginas ornamentadas, maridos e mulheres, pais e filhos, primos, afilhados, irmãos. Assim, construía uma determinada representação do grupo familiar, para ser propagada no tempo e reiterada pelo ato de recordar.

A manutenção do nome e da tradição familiares integrava o conjunto de patrimônios e riquezas definidor do habitus de classe da classe senhorial oitocentista. Por isso, a construção de uma dada memória coletiva familiar era condição fundamental não só para a coesão interna do grupo, como também para que, na escala social hierárquica em que se fundava a sociedade imperial, este se diferenciasse dos demais. $\bigcirc$ retrato fotográfico foi largamente utilizado
16. A pose é o símbolo maior do retrato oitocentista. Inicialmente (devido às limitações técnicas que sujeitavam o fotografado a um demorado tempo de exposição), eram necessários o imobilismo, a pose, a postura estudada, para possibilitar a fixação da imagem. No entanto, mesmo com os avanços técnicos, o jogo social fundado pela pose se mantém. "De modo que o tempo de exposição numa fotografia não pode ser visto como um mero dado técnico, configurando-se como um dado sociológico e histórico, pois o tempo de exposição é também o tempo social necessário para que o indivíduo represente seu papel num determinado cenário, onde a composição desse espaço e a captação desse momento são atributos especiais do fotógrafo." (TURAZZI, 1995, p. 14).

17."A análise histórica da mensagem fotográfica tem na noção de espaço a sua chave de leitura, posto que a própria fotografia é um recorte espacial que contém outros espaços que a determinam e estruturam, como, por exemplo, o espaço geográfico, o espaço dos objetos (interiores, exteriores e pessoais), o espaço da figuração e o espaço das vivências, comportamentos e representações sociais." (MAUAD, 1996, p. 81). 
18. Surgido em 1866, o cartão cabinet ou cabinet size constituía-se de uma imagem de $10 \times 14 \mathrm{~cm}$ colada sobre um cartão de $11 \times 16,5$, aproximadamente. como um material de memória coletiva e desempenhou o papel simbólico de legitimação da família. Nesse sentido, sua análise possibilita ir muito além da simples descrição e, assim, decodificar valores e idéias, recuperando as formas de agir e pensar no interior do grupo familiar num dado tempo e espaço. Para tanto, acredito que os retratos devem ser analisados levando em consideração uma série de elementos: o circuito social da fotografia, as lógicas técnicas e estéticas de sua produção, as estratégias de produção de sentido, em que se inserem a negociação da pose, a hierarquização dos personagens no espaço da figuração da foto, a ambientação ilusória montada e, finalmente, a narrativa composta nos álbuns pela disposição e ordenamento das imagens.

primeiro álbum pertencente à viscondessa possuía dois tipos de disposição: um cabinet-size ${ }^{18}$ ou quatro cartes de visite por página. Sua composição foi realizada ao longo de mais de trinta anos, contendo fotografias desde a década de 1860 até 1890. Certamente, o ato de preencher um álbum que não pretendia obedecer a uma cronologia requeria sua reelaboração constante, à medida que as novas imagens chegavam de presente ou eram tiradas pela família. Vejamos, portanto, a disposição final desse álbum da viscondessa (Álbum 1), caracterizado por ter capa de madeira e aplicação de monograma em prata.

Na primeira página, foi disposto um cabinet-size do Imperador no exílio, tirado em Cannes, em 31 de março de 1890 (Figura 1). A letra e a assinatura do Imperador demonstravam aos leitores visuais da coleção a proximidade dos Ribeiro de Avellar com a Família Imperial. As imagens seguintes,

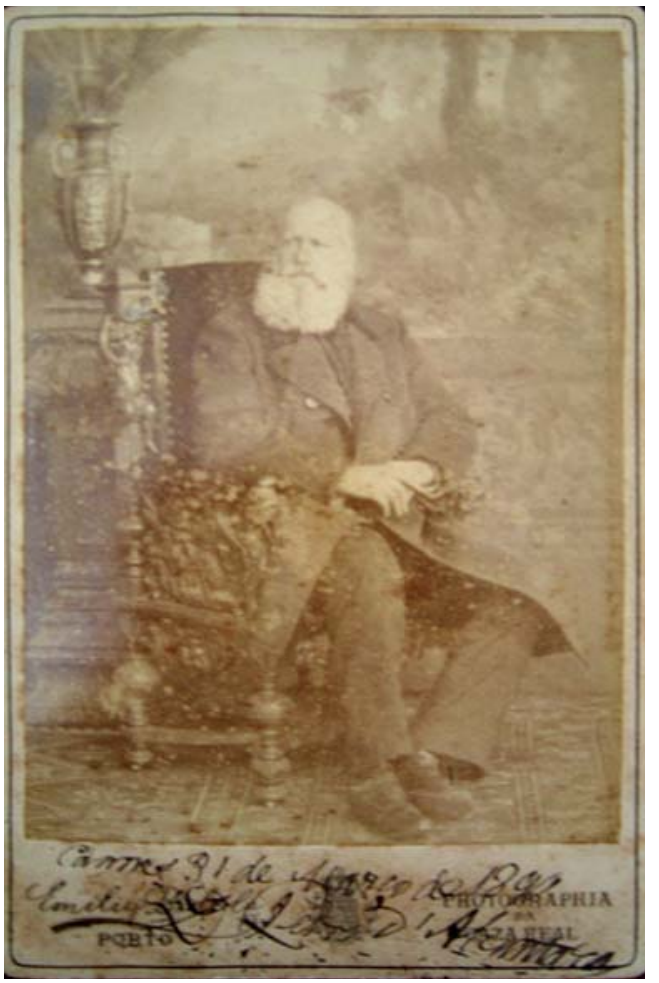

Figura 1 - D. Pedro II no exílio. Emílio Biel, cabinet-size, Cannes, 31 de março de 1890. Álbum da viscondessa de Ubá, Marianna Velho de Avellar (Álbum 1). Coleção particular 1 . 
no mesmo formato, eram da Imperatriz Tereza Christina (1874) e de D. Pedro, utilizando farda militar, logo após a Guerra do Paraguai (1870). Em seguida, vinham os cartes de visite da família Imperial, contendo novas fotos dos Imperiais, das princesas, do conde D'Eu, do príncipe do Grão-Pará e do primogênito da princesa Isabel, de Blanche D'Orleans e da princesa Januária, irmã de D. Pedro II, muitas delas dedicadas e assinadas. Na página sete, dividindo espaço com a princesa Januária e a condessa de Áquila, vinham o marquês e a marquesa de Itanhaém, membros da nobreza, de grande proximidade com os Imperiais e amigos da família Velho da Silva, tendo sido padrinhos do casamento de Marianna com Joaquim Ribeiro de Avellar. Dadas as devidas apresentações visuais, demonstrando estar no topo na escala social do Império, as páginas seguintes eram preenchidas por imagens de membros da família extensa.

A ordenação escolhida procurava fazer uma apresentação familiar do casal visconde e viscondessa de Ubá. As imagens do conselheiro José Maria e de D. Leonarda Velho da Silva ficavam no alto, seguidos por uma foto do casal Marianna e Joaquim, e de outra, da viscondessa sozinha, no estúdio de Joaquim Insley Pacheco, tirada no mesmo dia da fotografia da mãe. Na folha ao lado, havia duas fotos do barão do Capivary, uma de sua irmã e outra de Joaquim Mascarenhas Salter, todas tiradas pelo fotógrafo itinerante Manuel de Paula Ramos, em uma das ocasiões em que estivera na fazenda. Ao pousar o álbum sobre a mesa ou o colo, quem o visualizava podia ver qualificadas, ao mesmo tempo, as principais personagens das duas casas familiares: à esquerda, os Velho da Silva e à direita, os Ribeiro de Avellar (Figuras 2 e 3).
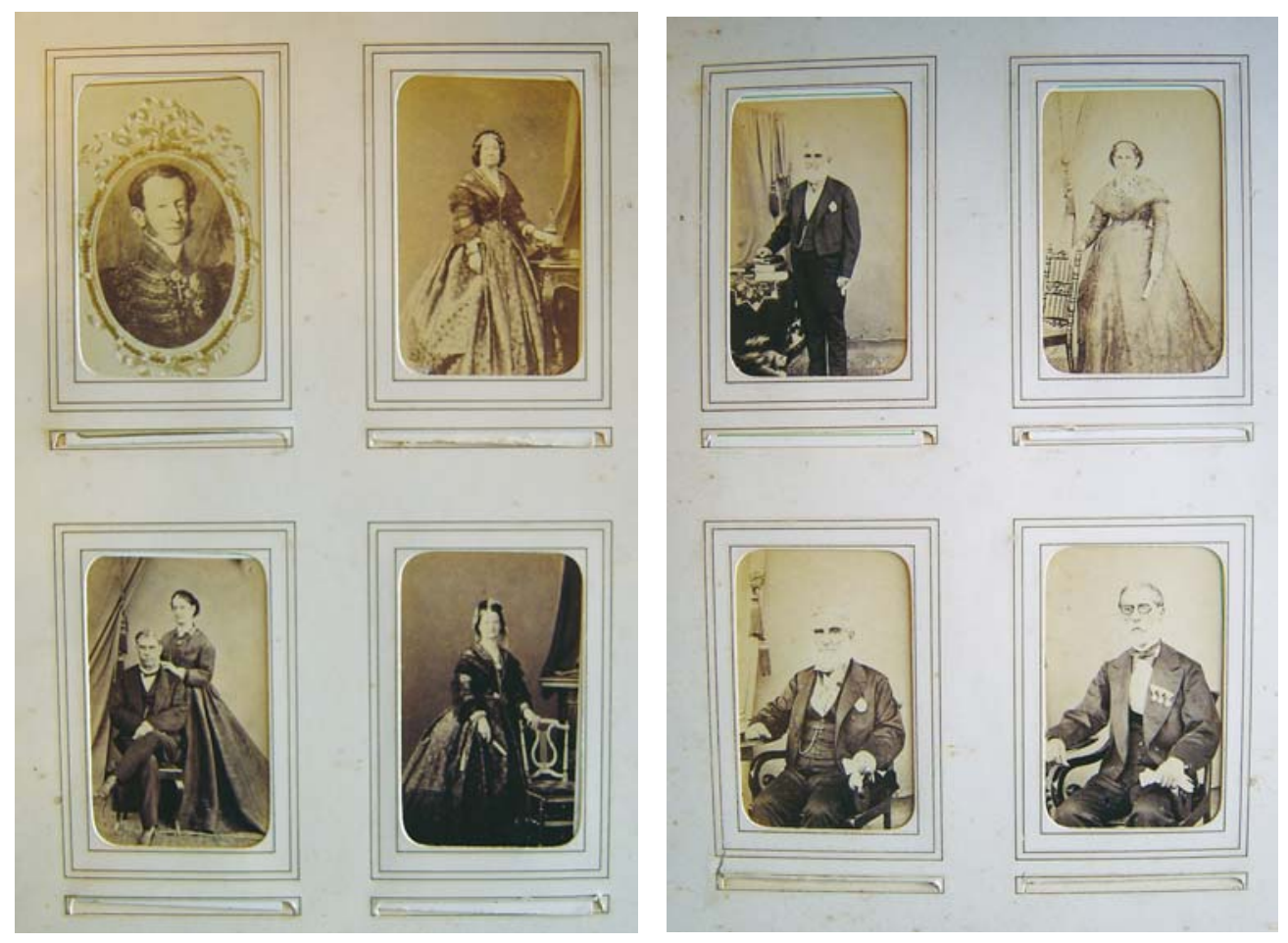

Figuras 2 e 3 - Narrativa visual regida pelo ideal de família extensa. Páginas do Álbum 1, aberto. Álbum da viscondessa de Ubá, Marianna Velho de Avellar (Álbum 1). Coleção particular 1 . 
Adiante, eram apresentados novos cabinet-size ocupando uma página para cada fotografia. A narrativa visual retornava à Família Imperial, enfocando mais especificamente o casal D'Eu, em imagens dotadas de uma certa atmosfera intimista. Nas duas primeiras, a princesa lsabel pousava para o fotógrafo F. Chardonnet, abraçada com o filho, em seu estúdio em Lyon. A seguir, aparecia sob a lente de Henschel \& Benque, acompanhada do marido e do primogênito. Nessa imagem o príncipe Pedro era alçado à centralidade da foto, e a princesa Isabel olhava diretamente para ele. Havia ainda uma imagem da princesa com Mariquinhas, filha mais velha do casal Ribeiro de Avellar e dama de companhia da princesa. Na belíssima fotografia de Numa Blanc Fils, a posição das mãos e o efeito flou desenhavam um coração que envolvia as retratadas, reafirmando uma amizade que vinha desde a infância (Figura 4). E, finalizando, um busto do conde D'Eu com a seguinte dedicatória (Figura 5):

Ao Sr. Coronel Joaquim Ribeiro de Avellar em signal da cordial estima e particular amizade com as mais afetuosas lembranças [,] offerece Gaston D'Orleans [,] 1877.

Ao continuar a folhear este precioso objeto da memória familiar, o leitor era levado a uma profusão de imagens; de filhos, netos, parentes, amigos

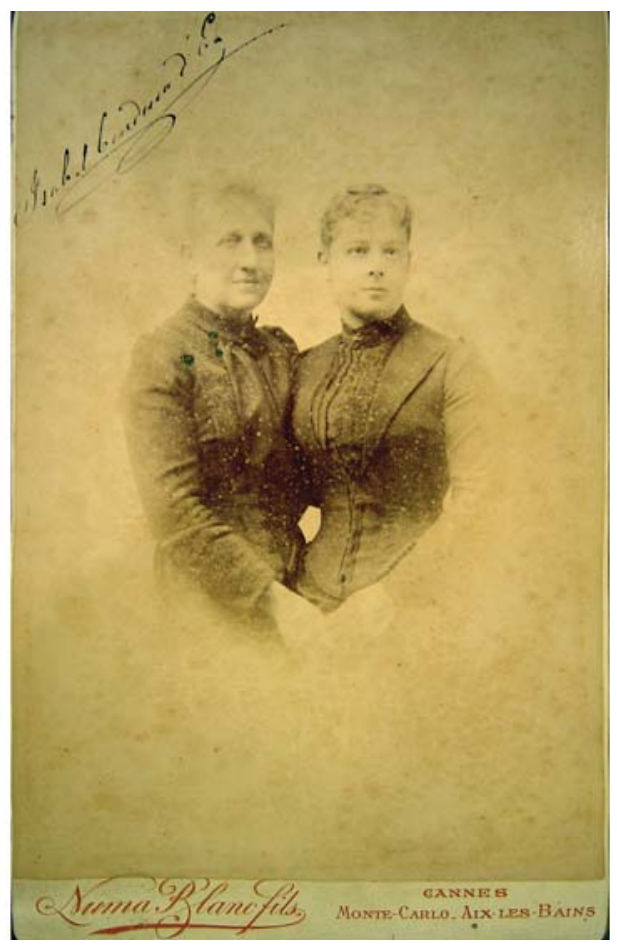

Figura 4 - Princesa Isabel e Mariquinhas. Numa Blanc, carte de visite, [s. d.]. Álbum da viscondessa de Ubá, Marianna Velho de Avellar (Álbum 1). Coleção particular 1 .

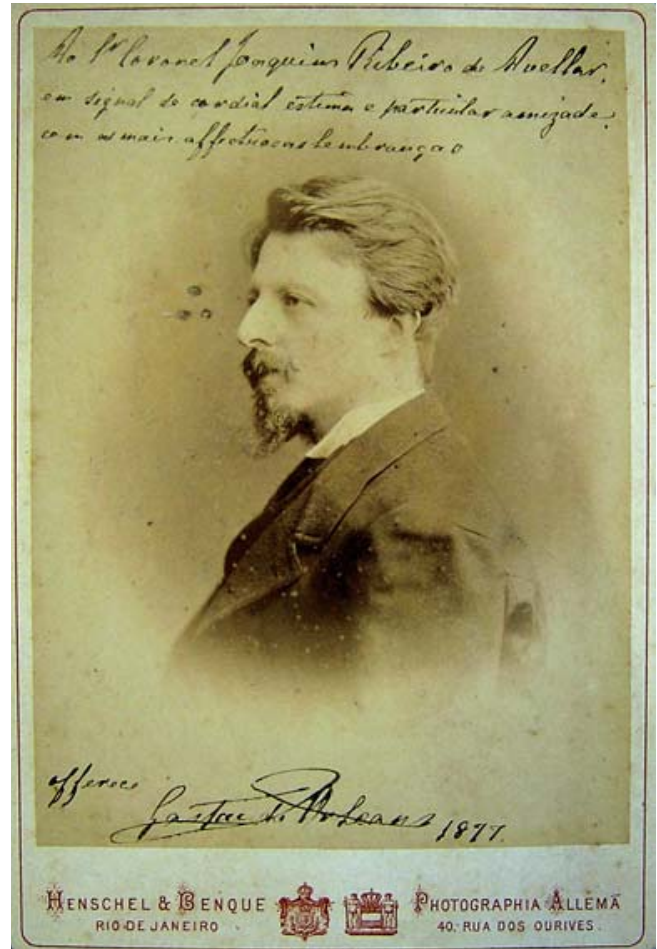

Figura 5 - Conde D'Eu. Henschel\&Benque, carte de visite, 1877. Álbum da viscondessa de Ubá, Marianna Velho de Avellar (Álbum 1).Coleção particular 1 . 
e compadres, além de outros pares da nobreza imperial como a baronesa de Fonseca Costa, a baronesa de Ourém e a condessa de Aljezur. Ao fim e ao cabo, estava apresentada a rede de sociabilidade e amizade com a qual os Ribeiro de Avellar queriam se ver identificados. Entretanto, os significados fornecidos à imagem envolvem uma esfera mais ampla de percepção, pois são também de competência de quem as observa e decodifica. A compreensão desejada depende das regras culturais compartilhadas pelos outros indivíduos envolvidos em sua produção, consumo, troca, organização e recepção.

A leitura das imagens, sua organização e disponibilização nos álbuns permitem afirmar que a representação familiar havia mudado de registro. Apresentava-se, singularmente, através de indivíduos antenados com um novo habitus aristocrático e com um padrão de civilização essencialmente urbano. $\bigcirc$ valor da família era manifestado através das qualidades dos sujeitos expressas em sociedade: educação, refinamento, bom casamento, moral, etiqueta, dentre outros. Valores que, em última instância, eram fornecidos, cultivados e agenciados no interior da família. A família oitocentista, enquanto cânone, sofria mudanças e ressignificações, contudo se mantinha como principal registro através do qual os indivíduos entendiam seu lugar e papel de atuação no mundo. Desta forma, apesar de as imagens reforçarem a representação individual, sua ordenação tecia um feixe de memória que valorizava a família extensa e seu poder, através de suas redes de sociabilidade e laços de amizade.

Outras práticas sociais também são capazes de atestar a importância da parentela na classe senhorial oitocentista. Apesar de ser um ato individualizado, recomendar-se sinceramente aos novos parentes nas cartas enviadas seria uma forma de confirmar os laços de fidelidade, consagrados através da união matrimonial que agregou dois diferentes grupos consangüíneos. Com a conseqüente consolidação das relações, buscava-se o fortalecimento da família como um todo:

\footnotetext{
Igualmente te peço que me recomende muito ao Sr. Barão, agradecendo-the por mim tantos obséquios que me fez e também a vovó Tonha, tia Annica, tia Maria moça e tia velha, a José Mascarenhas e Joaquim e ao Boaventura ${ }^{19}$

Meus respeitos ao Sr. Barão, a Sra. D. Antônia e a todos os teus parentes e acredita que são de coração ${ }^{20}$.

Dá-the muitas saudades assim como a Joaquim e muitos beijinhos as meninas e saudades a todas as senhoras tuas parentas ${ }^{21}$.
}

Através da aquisição gradual de intimidade e sentimentalidade entre membros de parentelas anteriormente distintas, desejava-se o fortalecimento interno da casa familiar como um todo. Na análise serial das correspondências de D. Leonarda para a viscondessa, por exemplo, percebe-se que o tom distante e cerimonioso, dispensado aos parentes da filha nos primeiros anos, vai sendo substituído por palavras mais calorosas, à medida que a convivência se estabelecia: "minhas saudades a D. Antônia e Maria, a Joaquim e José Mascarenhas" 22 . A troca de cartes de visite e seu envio a parentes também serviu
19. Carta de José Maria Velho da Silva para Marianna Velho de Avellar. Petrópolis, quarta-feira, 13 de dezembro (Coleção Particular 2).

20. Carta de José Maria da Silva Velho para sua irmã, Marianna Velho de Avellar. Catete, 4 de dezembro de 1855 (Coleção Particular 2).

21. Carta de Leonarda Maria Velho da Silva para Marianna Velho de Avellar. Rio, 27 de maio de 1854. (Coleção Particular 2).

22. Carta de Leonarda Maria Velho da Silva para Marianna Velho de Avellar. Petrópolis 12 de agosto de 1866 (Coleção Particular 2). 
23. O principal atrativo do carte de visite era o de oferecer mais por menos. Sua invenção, além de ocasionar uma queda no preço da fotografia, criou a facilidade de dispor de retratos suplementares para presentear, pouco importando ao público se o mais numérico representaria um menos na qualidade artística e técnica (VASQUEZ, 2003, p. 39).

para estreitar e atualizar os laços familiares no âmbito privado ${ }^{23}$. As dedicatórias, que podiam vir na frente ou no verso dos pequenos cartões, eram um mimo delicado dispensado aos entes mais queridos.

Remeter um carte de visite tinha a dimensão de "dar um pouquinho de si". Compartilhar o registro de uma imagem, um presente que o tempo se encarregaria de tornar mais raro, por remeter a um passado inalcançável. Dedicálo significava tentar traduzir em palavras um dado tipo de afeto. Assim procedeu Carolina Monteiro Velho, nora de Marianna Velho de Avellar, ao oferecer sua foło com a filha Maria Isabel para D. Antônia Ludovina, prima de Joaquim Ribeiro, a quem afetuosamente chamou de excelentíssima irmã. Sua imagem ressaltava seu papel como mãe e esposa, principais encargos da mulher oitocentista. No caso de Antônio Velho de Avellar, a denominação de avó também tratava de uma consideração afetuosa a alguma parenta idosa bastante próxima, já que sua única avó, D. Leonarda, havia falecido em 1871. A escolha do formato oval valorizava o indivíduo no espaço da figuração e foi bastante utilizado, principalmente, nas figuras masculinas da coleção. Já a baronesa de Muritiba, filha primogênita da viscondessa de Ubá, enviou sua imagem fotográfica tirada pelo conceituado fotógrafo Numa Blanc, de Paris, alguns meses depois de partir para o exílio acompanhando a Família Imperial (Figuras 6 a 9).

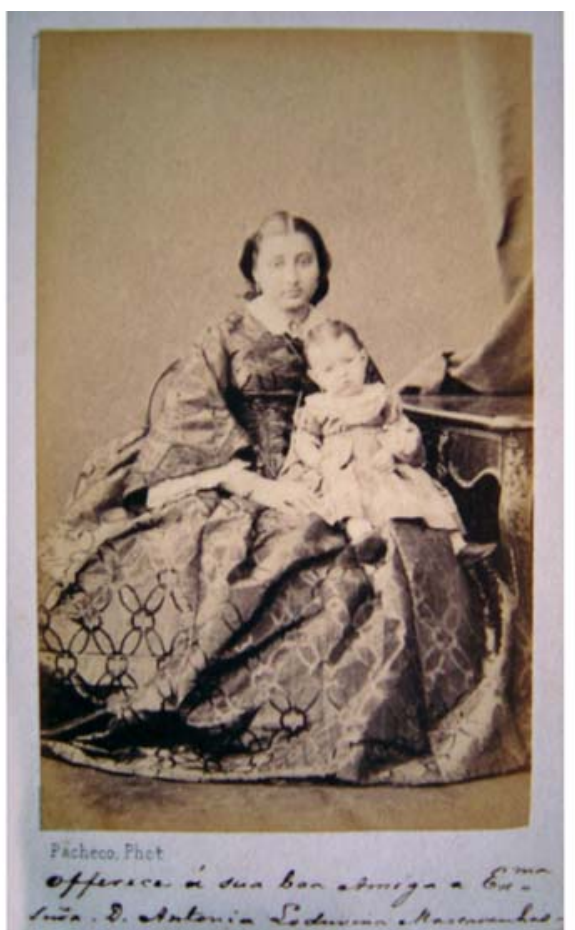

Figura 6 - Carolina Monteiro Velho. Pacheco Phot., carte de visite, 1864. Coleção particular de Roberto Menezes de Moraes.

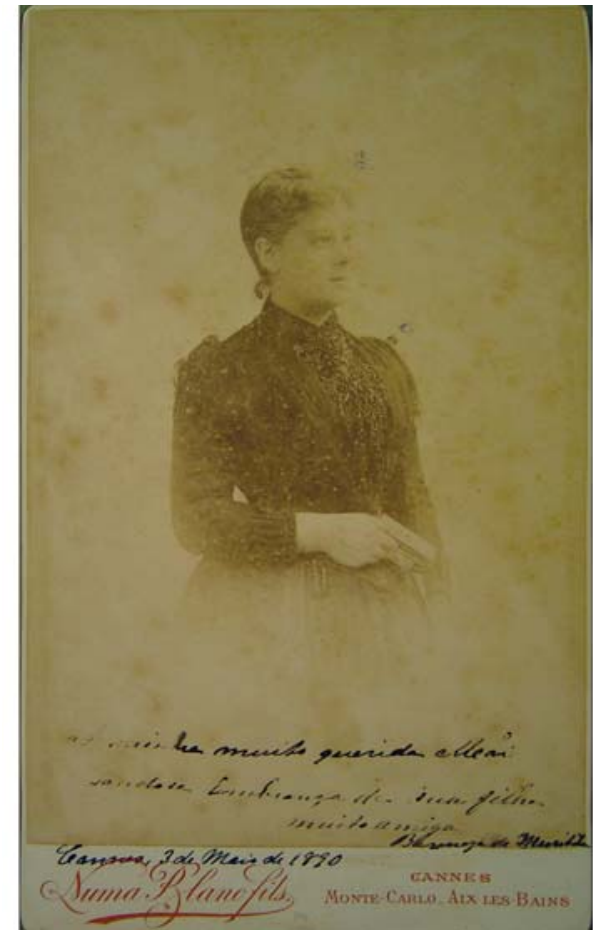

Figura 7 - M. José de Avellar Tosta. Numa Blanc, carte de visite, 1890. Álbum da viscondessa de Ubá, Marianna Velho de Avellar (Álbum 1). Coleção particular 1. 

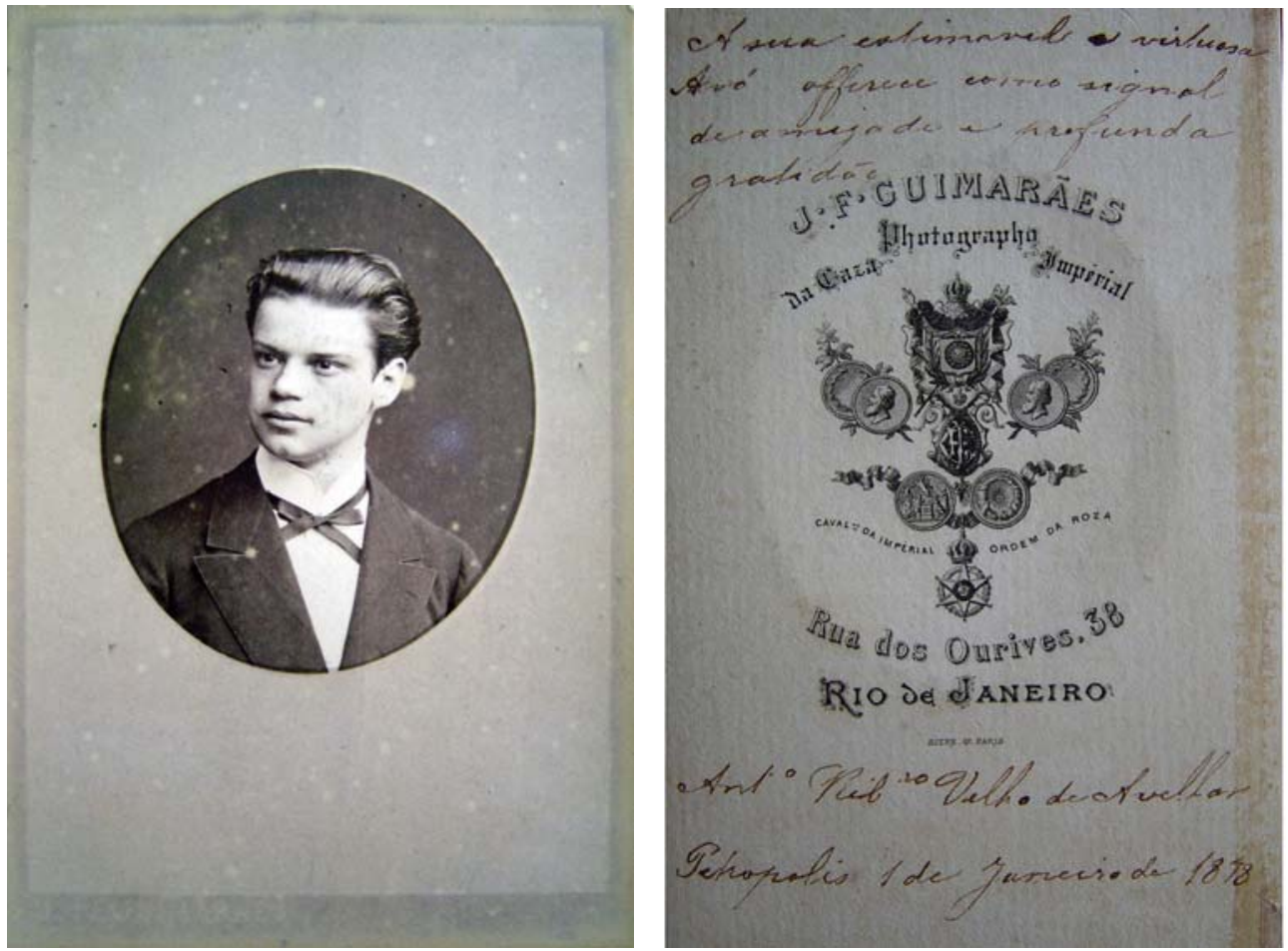

Figuras 8 e 9 - Antônio Ribeiro. J.F.Guimarães, frente e verso de carte de visite, 1878. Álbum da viscondessa de Ubá, Marianna Velho de Avellar (Álbum 1). Coleção particular 1.

Os cartes de visite, dedicados ou não, demonstram que as teias familiares traçadas se estendiam não só aos membros da família nuclear com descendência direta, mas também a parentes mais distantes. A distribuição de tais lembranças servia para estreitar laços já portadores de uma história afetiva pregressa. A importância da fotografia na construção das relações familiares confirma-se até mesmo numericamente. Dentre as 231 imagens que compõem a série documental dos Ribeiro de Avellar, 92, ou seja 40\% de seu total, são de pessoas da família, extensa ou nuclear. Aliás, tal proporção tende a ser ainda mais elevada, porque há retratados não identificados que, muito provavelmente, também são parentes.

Portanto, a troca de cartes de visite, assim como suas dedicatórias, as recomendações epistolares, as visitas e contravisitas, o envio de presentes, a troca de favores faziam parte de um conjunto de práticas cotidianas que atuavam no sentido de fortalecer as relações afetivas entre os membros da parentela no seu âmbito privado. Contudo, a manutenção da ordem familiar oitocentista encontrava-se na fronteira entre o público e o privado. Por um lado, ela não era mais mantida somente através da autoridade do pater familias e do monopólio da violência sobre todos os membros do núcleo familiar. Havia uma necessidade de criar outras estratégias cotidianas, que passassem pela afetividade e pela intimidade entre os componentes do grupo familiar, o que demonstrava uma 
24. Sobre o modelo de família patriarcal, utilizo as clássicas referências de Gilberto Freyre (1987; 1996). Para o autor, o patriarcalismo era sobretudo produto de uma concepção autoritária da natureza das relações entre seus membros. Desta forma, não pode ser igualado à família extensa tendo por base uma composição domiciliar

25. Os locais aqui citados foram especificados a partir do levantamento dos estúdios fotográficos onde se produziram os car te de visite de pessoas não pertencentes ao grupo familiar Ribeiro de Avellar Dentre eles: Photographia Alemã de Hoenen (São Paulo); R. Contreras (Juiz de Fora); Hees Irmãos e Photographia R. Barão do Amazonas (Petrópolis).A essas informações foi acrescida a análise do conteúdo das cartas.

26. Grifo nosso. Carta de Marianna Velho de Avellar para D. Leonarda Velho da Silva, Pau Grande, 11 de julho de 1864 (Coleção Particular 2). alteração significativa no funcionamento familiar ${ }^{24}$. No entanto, essas mudanças nas estruturas sentimentais e formas de comportamento privadas tinham como finalidade principal legitimar a importância do grupo familiar no âmbito público, sendo uma condição essencial para a manutenção de seu prestígio, riqueza e importância político-social.

Verso e reverso da imagem: produção, consumo e circulação social dos retratos da viscondessa

Renomados fotógrafos nacionais e internacionais compuseram a coleção Ribeiro de Avellar. Nesta ordem, J. F. Guimarães, Insley Pacheco, Alberto Henschel, Mangeon \& Van Nyvel, Carneiro e Tavares, foram os estúdios brasileiros que mais trabalharam para a família Ribeiro de Avellar. Entre os estrangeiros, figuraram: Mon. G. Le Gray \& Cie., Mourgeon Lucc, Numa Blanc Fils, A. Guesquin, P. Frois, Photographie Modèle, Photographie Walery, J. Couturier e A. Fillon Photo. O verso da fotografia oitocentista, assim como a própria imagem revelada, buscava uma hierarquização. Os estúdios mais caros, os fotógrafos condecorados ou premiados nas exposições nacionais e internacionais constituíam um status a mais na disputa pelo capital simbólico. Nesse aspecto, a contribuição de D. Pedro II foi marcante. Os melhores artistas do ramo que fotografavam a monarquia brasileira eram agraciados com o título de Photographo da Casa Imperial, o que valorizava bastante seu ofício e o preço do produto oferecido.

A encomenda de cartes de visite, formato presente em $90 \%$ da coleção estudada, e a escolha de ateliês consagrados para sua produção demonstram ser este um meio fundamental de expressar reciprocidade nas amizades e consolidar os laços afetivos entre os membros da chamada boa sociedade. Escolher um bom estúdio, além de ser uma garantia da imagem técnica, dava prestígio ao fotografado. Tais teias de relacionamento eram tecidas nos mais diferentes níveis e distâncias, mantendo o contato com famílias de Vassouras, Petrópolis, Corte, Juiz de Fora, Recife, Rio Grande do Sul e outras residentes ou a passeio na Europa ${ }^{25}$.

\section{Pau Grande, 11 de julho de 1864.}

Minha querida mãe,

Foi com muito prazer que recebi sua carta pelo nosso José Maria, e grande satisfação nos deu a vinda dele e pelo serviço que aqui nos fez deixou-nos inteiramente tranqüilos sobre inventários. Ele fez-nos um grande serviço ainda cá nesta ocasião. Teria sido grande prazer minha boa mãe se a [senhora] tivesse vindo também com ele; porém aqui daqui há pouco tempo teremos a estrada de ferro até Ubá, e então nos será mais fácil ver-nos assíduas vezes. Mamãe faltou-me mandar o meu retrato para Europa, me parece melhor esperar que Joaquim tire para ir os de toda a família ${ }^{26}$.

Nesta carta, a sra. Avellar colocava em dia uma série de notícias. Falava dos excelentes trabalhos realizados pelo irmão na abertura do inventário 
do sogro barão, da saudade da mãe, e da expectativa que a chegada da estrada de ferro até Ubá facilitasse o transporte entre a província e a Corte, aumentando o contato entre os parentes. Por fim, revelava sua intenção de apressar o envio dos retratos de sua família para amigos ou familiares na Europa. As fotografias eram individuais, mas deveriam ser remetidas em conjunto, ressaltando o grupo familiar, restando somente o retrato do marido Joaquim para ser providenciado.

A organização cronológica da série de imagens por fotógrafo permite vislumbrar microconjuntos de fotografias tiradas no mesmo dia, no mesmo estúdio e, em alguns casos, com o cenário idêntico. No ano de 1864, foram produzidos, no estúdio de Insley Pacheco, cinco retratos de membros da família. Compareceram à rua do Ouvidor 102, vestidos com suas melhores indumentárias, a mãe e o irmão da viscondessa - D. Leonarda e José Maria (Juca) -, além da própria, acompanhada dos filhos Mariquinhas, Luiza, Júlia e Antônio Ribeiro. É bem provável que sejam os mesmos citados na correspondência acima, pois não era comum a contratação de profissionais mais do que uma ou duas vezes por ano, a não ser em ocasiões especiais, como casamentos e formaturas. Juntamente com J. F. Guimarães (35\%), Insley Pacheco (33,3\%) era o retratista nacional mais requisitado pelos agentes familiares em questão. Sua escolha, portanto, só confirmava uma tendência (Figuras 10 a 12).

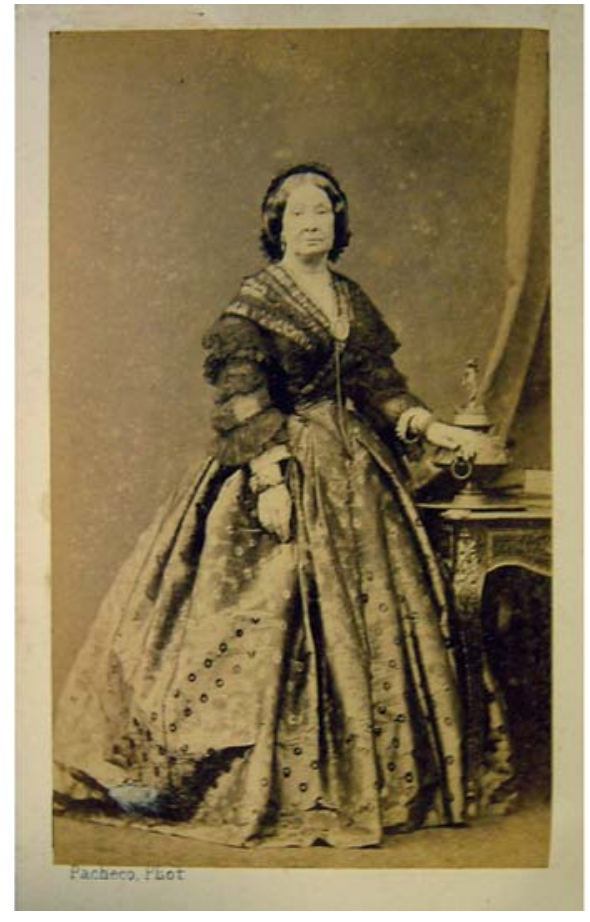

Figura 10 - D. Leonarda. Pacheco Phot, carte de visite, 1864. Coleção de Roberto Menezes de Moraes.

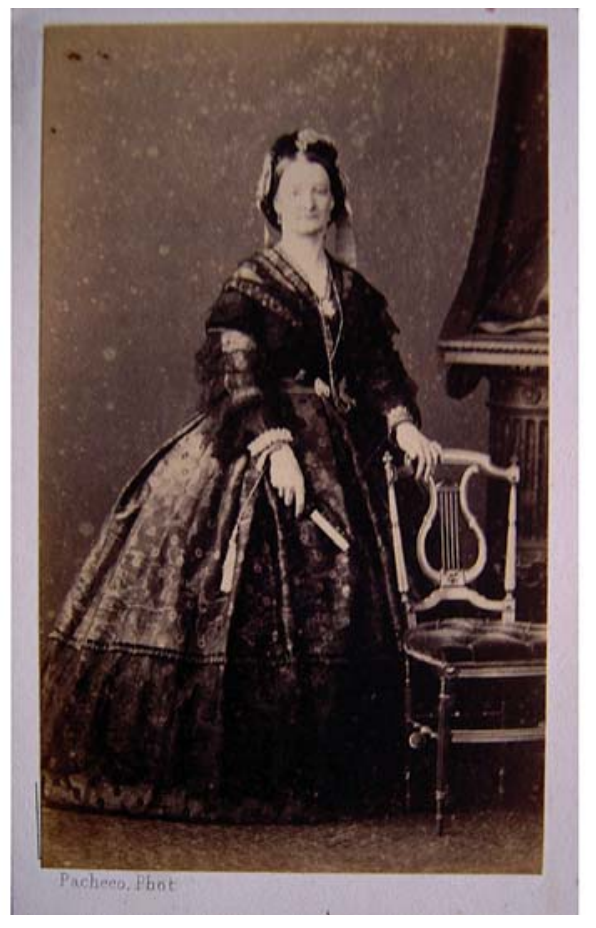

Figura 11 - Marianna de Velho Avellar. Pacheco Phot, carte de visite, 1864. Coleção de Roberto Menezes de Moraes.

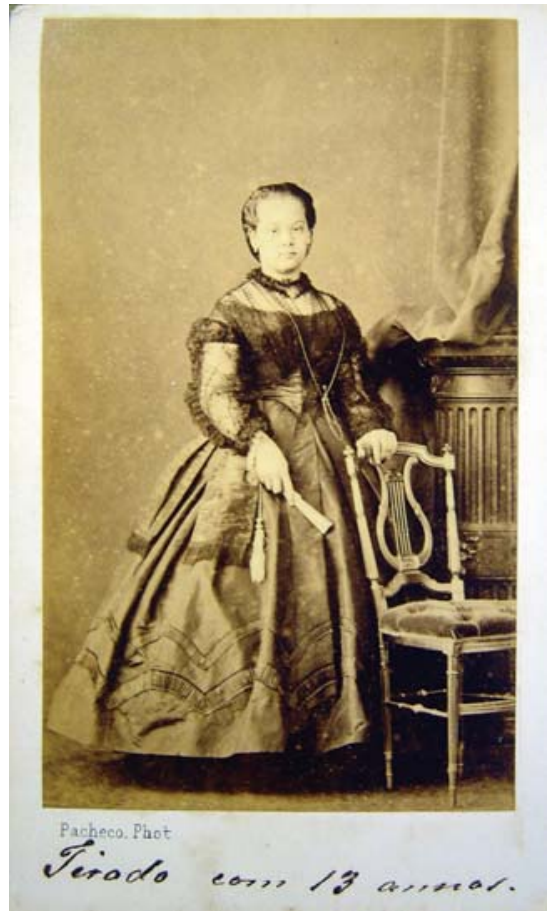

Figura 12 - M. José Velho de Avellar (Mariquinhas). Pacheco Phot, carte de visite, 1864. Coleção de Roberto Menezes de Moraes. 
A extensa lista de condecorações recebidas pelo fotógrafo, além de dar um ar sofisticado, investia simbolicamente na auto-representação desejada: Photografo da Casa Imperial, premiado na Exposição de 1861 e na Academia das Belas-Artes de 1864. Tanto D. Leonarda quanto Marianna Avellar e sua filha Maria José ocuparam o centro da imagem. As roupas escuras e os cabelos presos garantiam sobriedade às personagens. $\bigcirc$ leque, as jóias e a vestimenta rebuscada terminam de dar o tom refinado à foto, e eram valorizados pela exposição de corpo inteiro. Apesar de a pose ser quase a mesma nas três imagens, no que concerne à cenografia, houve algumas mudanças, no entanto, optou-se por poucos objetos. No caso de D. Leonarda, mesa detalhada e prataria serviam de leve apoio e adorno. Para Marianna e Mariquinhas, foram dispostos: um balaústre, uma cadeira esculpida com uma lira no encosto e uma cortina, para dar certo movimento ao fundo. Entretanto, nenhuma dessas escolhas era ingênua. As mulheres da família Ribeiro de Avellar almejavam perpetuar uma imagem condizente com os ideais de comportamento da elite imperial. Para tanto, valorizaram a música, um dos hábitos femininos mais bem vistos na classe senhorial, representada nos dois retratos pela lira. Da mesma forma, a busca de representações visuais tão próximas para avó, mãe e filha pretendia apontar uma semelhança de caráter, comportamento e prestígio em três gerações de mulheres da mesma família. Os outros retratos tirados no mesmo dia foram os das Figuras 13 e 14 .

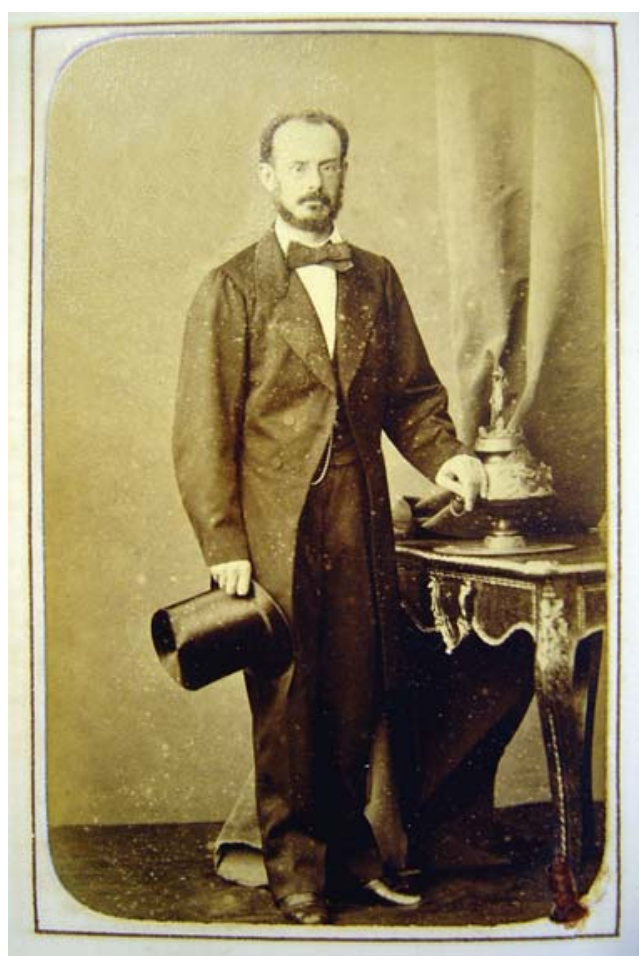

Figura 13 - Juca. Pacheco Phot, carte de visite, 1864. Coleção de Roberto Menezes de Moraes.

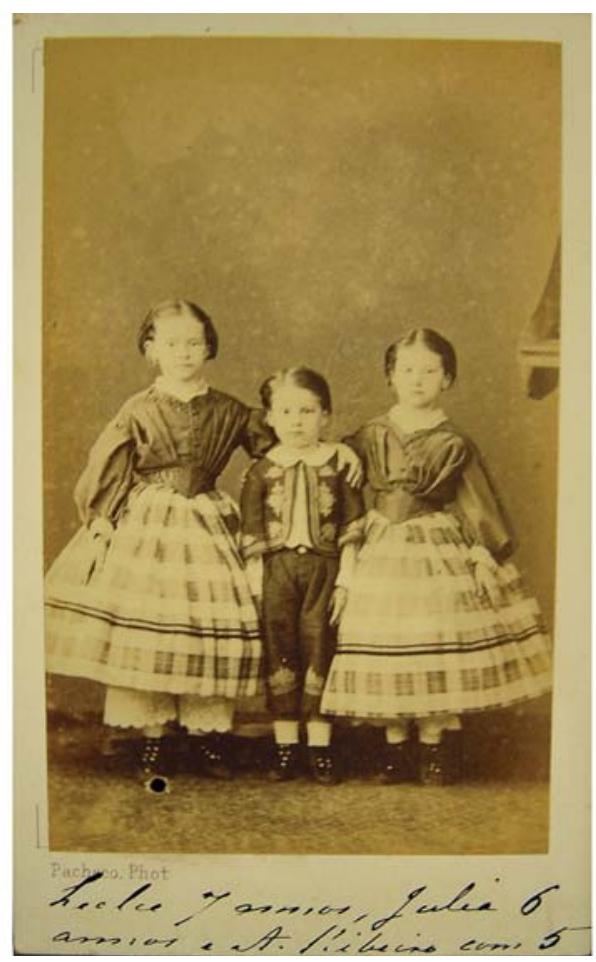

Figura 14 - Luiza, Júlia e Antônio Ribeiro. Pacheco Phot, carte de visite, 1864. Coleção de Roberto Menezes de Moraes. 
Enquanto o traje feminino adulto se apresentava rico em rendas, enfeites, fitas e detalhes, o masculino despojava-se até transformar-se numa espécie de uniforme. $\bigcirc$ cenário escolhido por Juca, irmão de Marianna, foi o mesmo que o da mãe, D. Leonarda, com uma pequena diferença em relação ao seu posicionamento na foto. Imbuído do desejo de distinção social, escolheu o que havia de mais elegante e moderno na indumentária masculina da época, combinando calça, colete, paletó e gravata ${ }^{27}$. Em uma das mãos, apresentava uma bela cartola e, discretamente, permitia a visualização da corrente de um relógio de bolso, símbolo de distinção e requinte. As crianças - Luiza, Antônio Ribeiro e Júlia - foram fotografadas em grupo e com vestimentas que as identificavam coletivamente. A elas era permitido um pouco mais de cor nos tecidos, além do xadrez e bordados, que contrastavam com o fundo escuro. $\bigcirc$ posicionamento dos indivíduos no espaço da figuração da foto buscava uma harmonia e tendia a uma linha reta, dando a eles uma equivalência de importância. Tanto o tio quanto os sobrinhos ficaram em pé, exibindo as luxuosas vestimentas e olhando fixamente para a lente do fotógrafo. Tais escolhas pretendiam contribuir para o tipo de representação desejada e faziam parte de um jogo em que fotógrafo e fotografado eram cúmplices na invenção de uma certa imagem a ser perenizada no tempo.

Fazendo, na coleção Ribeiro de Avellar, uma análise que particularize as imagens de familiares, é possível perceber que ir a um estúdio fotográfico não somente era uma prática realizada com assiduidade, como um ato coletivo. Tal afirmativa fundamenta-se no fato de terem sido encontrados vários outros microconjuntos de imagens, enquadrando diferentes membros do núcleo familiar, além dos já aqui apresentados.

Em 1867, por exemplo, Luiza (10 anos), Júlia (9 anos) e Antônio Ribeiro (8 anos) foram, novamente, na companhia da mãe, ao estúdio de Insley Pacheco (Figuras 15 e 16). Dessa vez, levaram com eles José Maria para tirar aquela que parece ter sido sua primeira fotografia, aos quatro anos de idade. Na composição escolhida para as duas fotografias, as crianças foram separadas por sexo e idade: Luiza com Júlia e Antônio Ribeiro com José Maria. Os irmãos fotografados dispuseram-se lado a lado e olharam fixamente para a lente do fotógrafo. O gestual denotava uma aproximação entre os retratados e uma posição protetora dos mais velhos para com os menores. No ano seguinte, o ateliê escolhido foi o de E. J. Van Nyvel, localizado na Rua dos Ourives, 65. Entretanto, os sujeitos retratados foram Júlia e Antônio Ribeiro, compondo uma imagem, e Mariquinhas, em outra imagem individual (Figuras 17 e 18).

Em relação à última foto, é interessante notar que, ao contrário de seus irmãos, Maria José Velho de Avellar, aos dezesseis anos, já posava com gestual, indumentária, adereços e penteado que a identificavam como mulher adulta. Não é possível saber ao certo se os outros filhos não foram fotografados ou, simplesmente, se suas imagens não conseguiram perdurar no tempo. Entretanto, é interessante ressaltar, como ficou registrado numa carta de D. Leonarda para Marianna, que nem sempre as viagens para a Corte eram feitas com todos os filhos. Às vezes, dividiam-se as crianças. Algumas saíam com a 


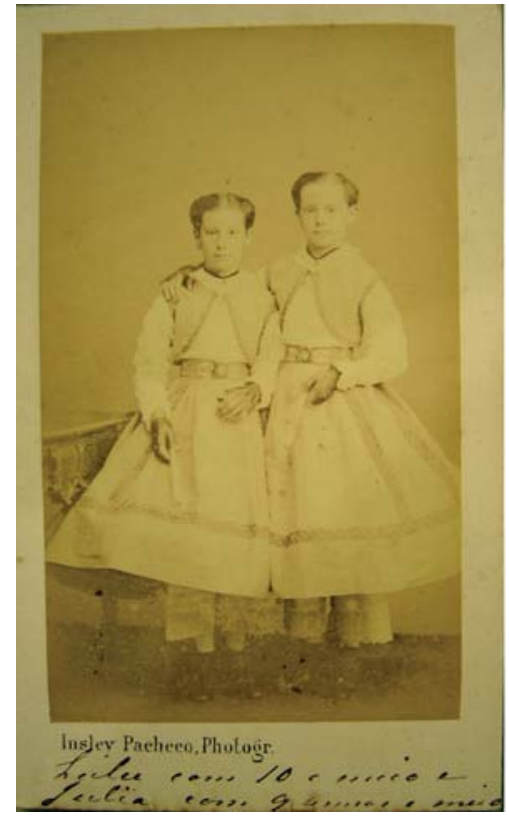

Figura 15 - Luiza e Júlia. Insley Pacheco, carte de visite, 1867. Álbum da viscondessa de Ubá, Marianna Velho de Avellar (Álbum 1). Coleção particular 1 .
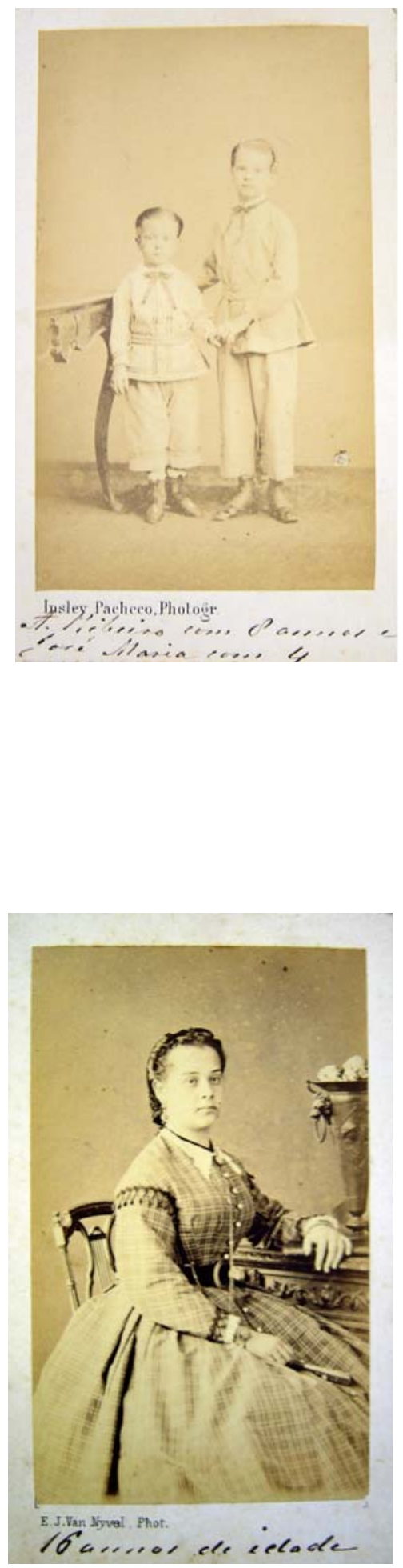

Figura 18 - Mariquinhas. E. J. Van Nyvel, carte de visite, 1868. Álbum da viscondessa de Ubá, Marianna Velho de Avellar (Álbum 1). Coleção particular 1 
mãe e outras ficavam na companhia dos avós ou vice e versa: "quanto à escolha que me propões não há que hesitar. Bem me entendes... Para sempre todos os seus filhos, porém tendo que escolher, sempre Mariquinhas" 28 .

A próxima vez que Mariquinhas se deixou fotografar pelo mesmo profissional foi em 1869, aos dezoito anos, às vésperas de seu casamento com Manuel Vieira Tosta, membro de uma tradicional família da política baiana. Para a ocasião, vestiu seu melhor vestido, jóias e pousou para duas imagens muito parecidas: a primeira com enquadramento aproximado e a segunda, mais distanciado, sendo retratada de corpo inteiro (Figuras 19 e 20). Já o noivo, doze anos mais velho e formado bacharel em ciências jurídicas por São Paulo, escolheu o estúdio de Mangeon \& Van Nyvel e pousou já casado (Figura 21 ). $\bigcirc$ matrimônio da primogênita com o filho do primeiro barão de Muritiba ${ }^{29}$, pertencente à elite política do Império, fundava novos laços de solidariedade entre duas parentelas distintas no sobrenome, mas que, certamente, ocupavam o mesmo patamar de riqueza e prestígio social. $\bigcirc$ pomposo cerimonial, entretanto, exercia uma dupla comemoração, pois foi realizado no mesmo dia em que Marianna e Joaquim Ribeiro de Avellar completavam vinte anos de vida conjugal ${ }^{30}$. Brindavam-se, assim, a novas e velhas uniões.
28. Carta de D. Leonarda Maria Velho da Silva para Marianna Velho de Avellar. Glória, 4 de março de 1854 (Coleção Particular 2).

29. Manuel Vieira Tosta, pai de Manoel Vieira Tosta Jr., nasceu na Bahia em 1807. Formou-se em direito em São Paulo e ocupou diversos cargos na política. Foi deputado e senador do Império e presidente das seguintes províncias: Bahia (1842), Sergipe (1843-1844), Pernambuco (1848-1849) e Rio Grande do Sul (1855). Foi ministro da Marinha, ministro da Justiça, ministro da Guerra e membro do Conselho do Estado. Possuía os títulos de Dignitário da Ordem do Cruzeiro do Sul e da Rosa e a comenda da Ordem de Cristo. Foi barão (1855),

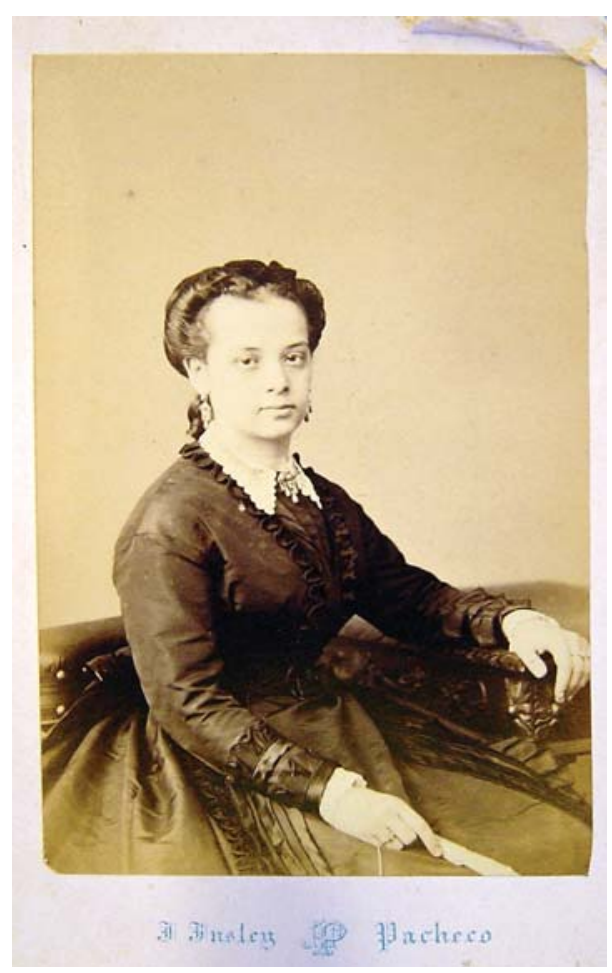

Figura 19 - Mariquinhas. Insley \& Pacheco, carte de visite, 1869. Álbum da viscondessa de Ubá, Marianna Velho de Avellar (Álbum 1). Coleção particular 1.

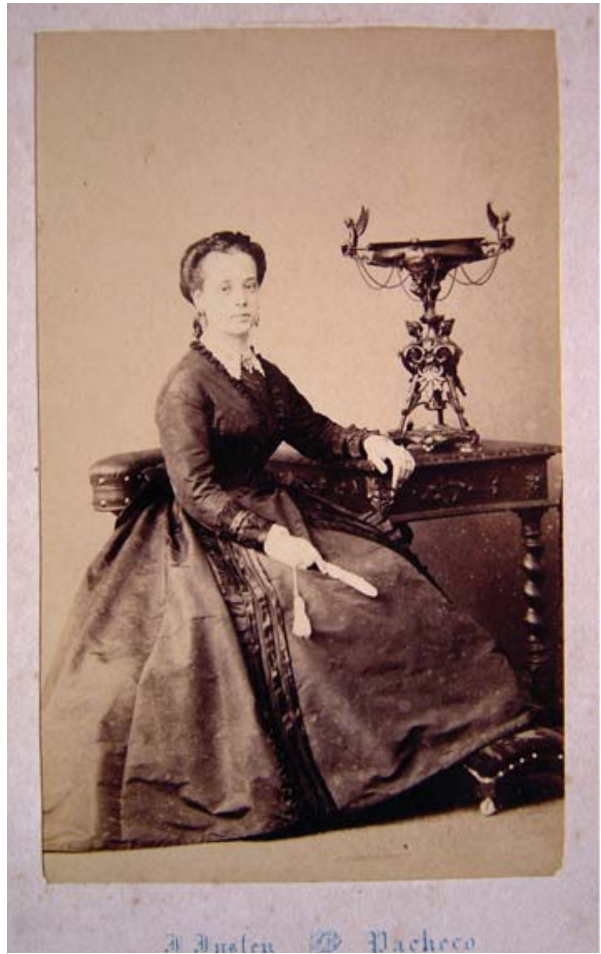

Figura 20 - Mariquinhas. Insley \& Pacheco, carte de visite, 1869. Coleção de Roberto Menezes de Moraes.

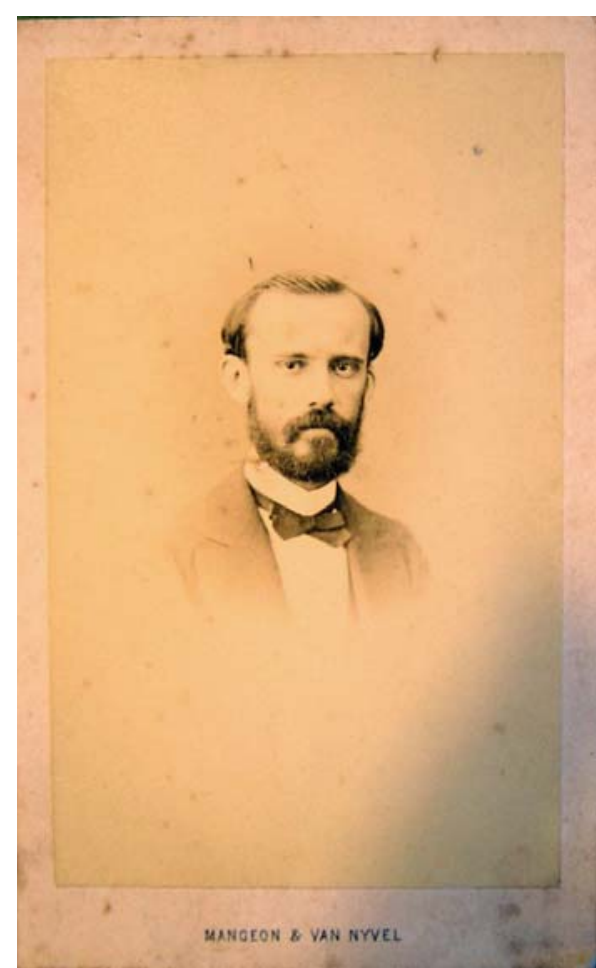

Figura 21 - Manoel Vieira Tosta. Mangeon \& Van Nyvel, carte de visite, 1870. Álbum da viscondessa de Ubá, Marianna Velho de Avellar (Álbum 1). Coleção particular 1. 
visconde (1872) e marquês de Muritiba, com Grandeza por direito (1888). Faleceu em 1896

30.Auto de casamento de Manoel Vieira Tosta e D. Maria José Velho de Avellar.Arquivo Nacional, Fundo Família Vieira Tosta, QE, Seção de Guarda SDP, Instrumento SDP 019, caixa 2, documento 1 .

31. Grifo nosso. Carta de Elisa Velho de Avellar para José Maria Velho de Avellar. Rio, 5 de setembro de 1884 (Coleção Particular 2)

32. Carta de Marianna Velho de Avellar para José Maria Velho de Avellar. Corte, 8 de setembro de 1884 (Coleção Particular 2)
Ir ao estúdio fotográfico antes e depois do casamento foi sendo, cada vez mais, integrado a um habitus de classe. A fotografia cumpria sua função simbólica de representação individual e familiar e, na década de oitenta, já estava totalmente popularizada entre as práticas familiares do cotidiano dos mais abastados. Às vésperas de se casar com Luiz de Souza Fontes, formado em medicina, e filho do médico do imperador, Dr. Souza Fontes, Elisa, filha caçula da viscondessa, escreveu a seu irmão José Maria, na época, estudante de Direito em Recife, contando:

Rio, 5 de setembro de 1884,

Meu querido irmãozinho,

Quanto estimei receber a sua cartinha; pois há tanto que não nos avistamos e ainda não nos é permitido mitigar um pouco as nossas saudades.

Receberás quase ao mesmo tempo uma cartinha do meu querido Luiz mandando-te o retrato dele.

Ontem fui ao baile da princesa, porém agora não danço pois pouco é o tempo para estar ao lado esquerdo do meu Luiz, que não faz senão me admirar principalmente quando estou de vestido novo.[...]

Estamos a espera de papai para organizarmos um projeto de mamãe, que é de dar uma soirée no dia do meu casamento, que será à tarde.

Adeus, meu prezado José Maria, aceita lembranças do Luiz e um saudoso abraço desta tua irmã que te ama sinceramente.

Elisa $^{31}$.

Tanto as imagens fotográficas quanto as correspondências eram utilizadas com a finalidade de estreitar os laços entre aqueles que ainda não se conheciam, mas, em breve, iriam se tornar membros de uma só família. Apenas três dias depois de Eliza ter escrito ao irmão, a Sra. Avellar remetia nova carta, confirmando o recebimento do prometido. Além disso, aproveitava e enviava a fotografia da filha antes de se casar: "desejo que você tenha recebido o retrato de seu futuro cunhado, pois me disse que também the escreveu. Envio a você dentro desta o primeiro de Eliza que veio para casa. Como você está longe é servido em primeiro lugar e os outros terão depois" ${ }^{\prime \prime 2}$. As palavras de Marianna deixam transparecer o quanto a fotografia estava integrada ao dia-a-dia do grupo familiar. A facilidade de reprodução e a crença na "fidelidade ao real" pareciam ser as características que mais seduziam. Ao final, revelava sua preferência por José Maria na distribuição dos cartes de visite da irmã, tendo em vista que estava estudando em outro estado e não a via com freqüência.

Corte, 14 de setembro de 1884 .

[...] $\bigcirc$ casamento será às 5 horas da tarde. Os convidados seguiram até a nossa casa do Catete onde haverá uma soirée dada aos noivos. Fora de nós de casa só irão suas primas Machadas e os demais convidados para o soirée. Nós estamos contentes, mas estamos descontentes por ter falecido o Duque Estrada e assim o Tosta e a Mariquinhas estão tristes, assistem ao casamento mas não sei se ao soirée. Vó Tonia é a madrinha, seu pai por escolha do noivo e Antônio Ribeiro por Eliza. 
Hoje vamos jantar na casa do Barão Souza Fontes. Ah! Quanto sinto você não estar presente. É essa uma das mágoas que me acompanha, espero que você reze por sua irmã e pela sua felicidade.

Adeus, saudades de todos nós, um abraço de sua mãe muito amiga

M. de Avellar.

A cerimônia religiosa foi na capela da casa do barão de Souza Fontes, seguida de um chá, oferecido no salão da mesma casa, e de uma soirée organizada pelos Ribeiro de Avellar, na residência do Catete. Uma semana depois de casados, Elisa e Souza Fontes partiram para Petrópolis por uma semana e, em seguida, pretendiam ir à Fazenda Pau Grande, para descansar com a família. A intimidade entre irmãos permitiu que José Maria fizesse um comentário engraçado sobre o cabelo de Elisa na fotografia de noivado recebida: "penteado de trepa moleque". A mãe respondeu-lhe que, depois de casados, a irmã e o cunhado regressariam ao estúdio para fazer a fotografia oficial do casal e, dessa vez, "não se penteou por cabeleireiro e estou certa que ficará melhor. Ainda não a vi porque ela só foi tirá-lo há três dias"33. As passagens demonstram o próprio circuito de recepção, leitura e ação da imagem fotográfica, que superavam o próprio ato de negociação entre retratista e retratado, eternizado no papel emulsionado ${ }^{34}$. Nem sempre o efeito desejado pelos envolvidos na produção da imagem era obtido ou reconhecido pelo leitor (Figura 22).

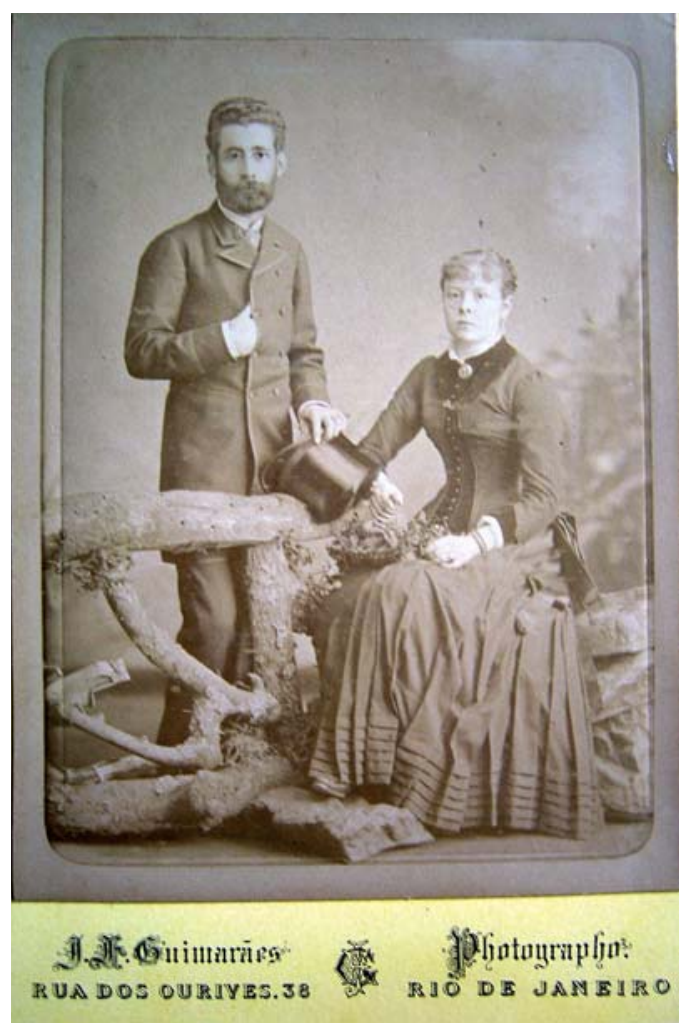

Figura 22 - Elisa e Luiz R. de Souza Fontes. J. F. Guimarães, cabinet-size, 1884. Álbum da viscondessa de Ubá, Marianna Velho de Avellar (Álbum 11.Coleção particular 1.
33. Carta de Marianna Velho deAvellar para José Maria Velho de Avellar. Corte, 6 de outubro de 1884 (Coleção Particular 2).

34. Segundo Ulpiano, as imagens não têm sentido em si mesmas, é a sua interação social que lhes produz sentido. Desta forma, propõe que elas devem ser analisadas em sua produção, circulação, consumo e ação social (MENESES, 2003). 
A ida aos renomados estúdios fotográficos podia ser impulsionada por diversos fatores. Por um lado, constituía-se numa prática coletiva e bastante difundida na vida familiar dos Ribeiro de Avellar. Quando viajavam para a Corte, deixar-se fotografar fazia parte de um conjunto de comportamentos pertencentes ao novo habitus refinado adquirido pelas famílias abastadas, assim como ir à Confeitaria Colombo, freqüentar teatros e óperas ou fazer compras na rua do Ouvidor. Por outro lado, havia ocasiões especiais e datas marcantes da vida pessoal, em que o objetivo era destacar um determinado membro da parentela. Neste último caso, é interessante ressaltar que a fotografia foi importante para a publicização de eventos que, anteriormente, estavam reservados à esfera familiar. Além dos casamentos, as imagens da coleção auxiliaram na divulgação e comemoração de formaturas e primeiras comunhões. Aos poucos, seus cerimoniais passaram por uma sofisticação e valorização pública, atuando como elemento de prestígio e delimitando os espaços de poder privilegiados para a classe senhorial.

Assim, esses eventos adquiriram um valor hierárquico externo e receberam um novo status de celebração, pois separavam os membros da aristocracia - que poderiam efetivar tais festas com todo requinte - daqueles que não tinham condições socioeconômicas para tal. Contudo, ao mesmo tempo, esse movimento de cisão é também passível de ser verificado no interior das melhores famílias, onde alguns teriam eventos e comemorações mais pomposas do que outros. Ou seja, aos poucos, o padrão de comportamento da classe dominante passou a atuar não só como uma marca de distinção entre os pares sociais, mas também como parâmetro para as demais camadas da sociedade. O registro fotográfico também acompanhou esse processo, passando a ficar cada vez mais freqüente à medida que tais eventos tomavam uma dimensão mais pública.

Nesse contexto, os registros fotográficos de meninos e meninas com roupa de primeira comunhão, e de estudantes recém-formados, passaram a ser cada vez mais utilizados como forma de comunicar as importantes ocasiões a parentes e amigos, e de fortalecer os laços de reciprocidade entre os pares sociais. Como a tecnologia fotográfica da época não permitia o registro visual de cerimoniais em ambientes fechados, como interiores das igrejas e de faculdades, tornou-se comum a ida ao estúdio fotográfico para posar e, posteriormente, distribuir os cartes de visite como recordação. No caso das fotografias de primeira comunhão, é interessante notar, no entanto, que, mesmo com todos os recursos oferecidos pelos ateliês - em termos de fundos, cenário e mobiliário -, em nenhuma fotografia da coleção eles foram utilizados no sentido de prover uma ambientação que imitasse o interior de uma capela, prevalecendo os móveis comuns (Figuras 23 a 25).

Os dois filhos mais velhos do visconde e da viscondessa de Ubá formaram-se em Direito pela Faculdade de Recife. O caçula José Maria concluiu seu curso em março de 1885 e, para comemorar essa etapa significativa na 


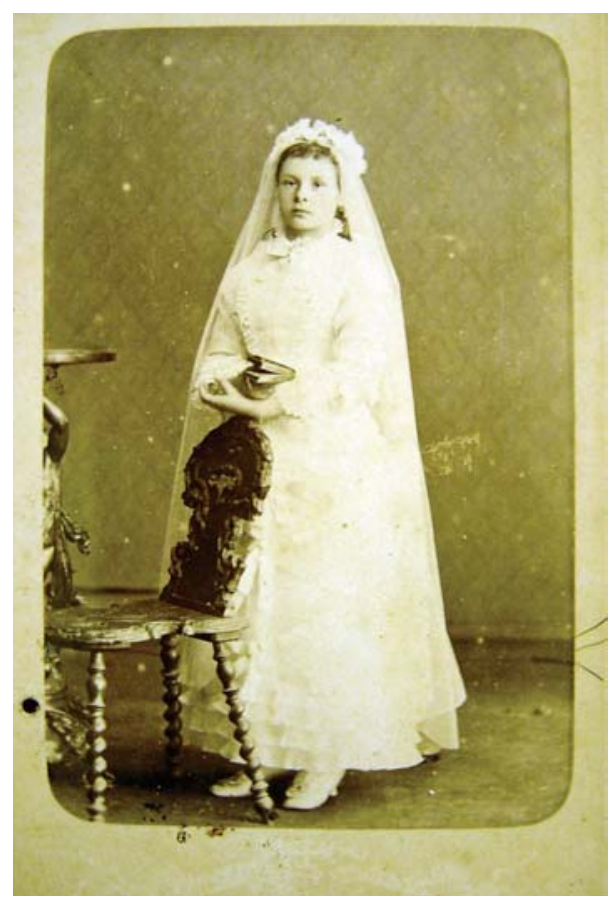

Figura 23 - Neta da viscondessa. J.F. Guimarães, carte de visite, s/d. Álbum da viscondessa de Ubá, Marianna Velho de Avellar (Álbum 1).Coleção particular 1 .
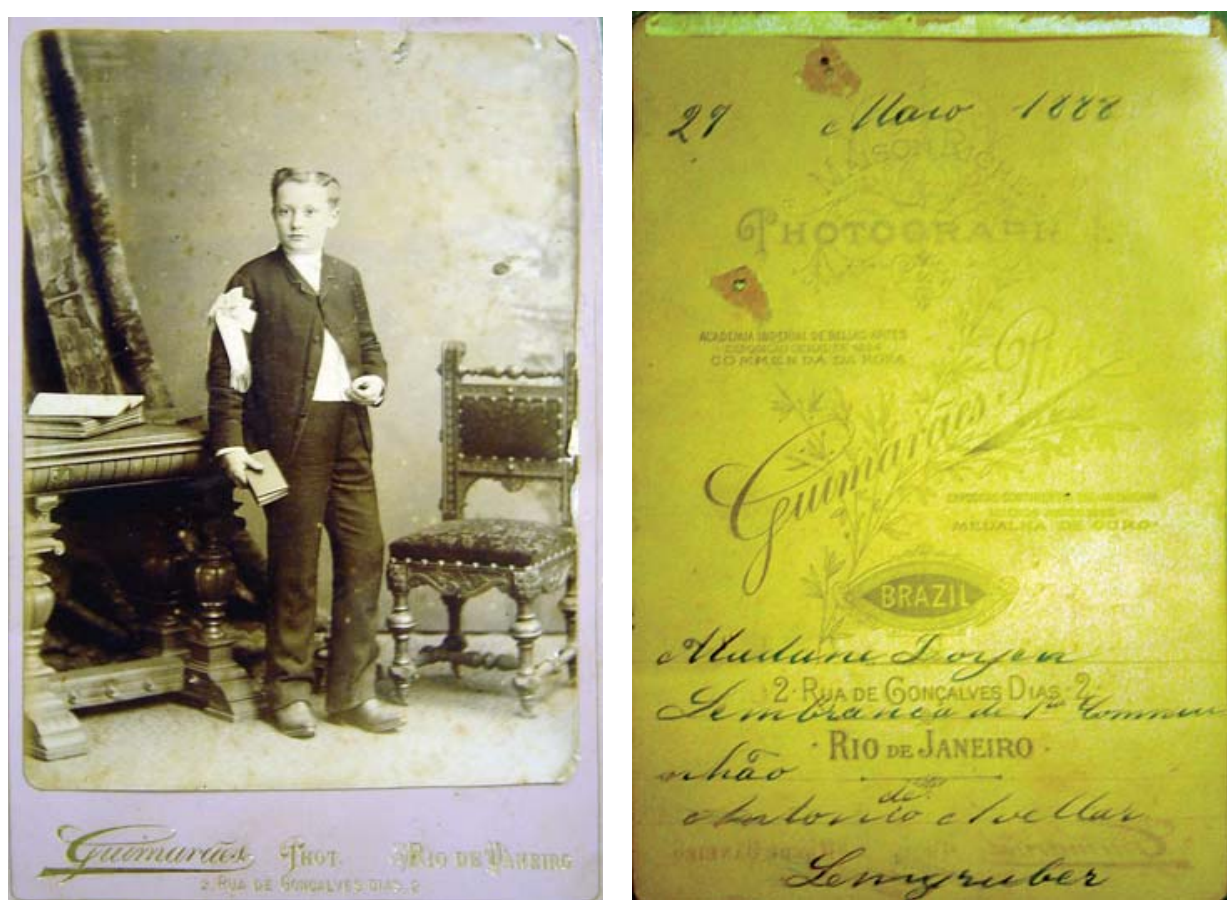

Figura 24 e 25 -Antônio Avellar Lemgruber. J.F. Guimarães, frente e verso de carte de visite, 1888. Álbum da viscondessa de Ubá, Marianna Velho de Avellar (Álbum 1).Coleção particular 1 . vida dos jovens da classe senhorial, compareceu ao estúdio de J. F. Guimarães, o mesmo em que, em 1882, seu irmão mais velho Antônio Ribeiro havia sido fotografado na mesma situação (Figuras 26 a 28).

As duas imagens seguiram o mesmo padrão fotográfico: recorte oval ressaltando os indivíduos retratados, que são dispostos em um plano principal, fundo escuro, meio-perfil e olhar indireto, que não se volta para a lente do fotógrafo. As vestimentas diferenciam-se pouco, provavelmente para se adequarem às exigências da moda em tão curto espaço de tempo. A nova etapa da vida vinha representada na seriedade do semblante e da indumentária. Estava cumprida mais uma etapa na criação dos filhos, socialmente entendida como de responsabilidade dos pais. Enfim, depois de tantas cartas, saudades e preocupações, a viscondessa podia comemorar: "Que prazer não tenho eu vendo-o formado e seguindo uma bonita carreira para assim ver mais um filho, feliz e empregado"35.

A análise serial das imagens da coleção da viscondessa pontua importantes datas comemorativas nas trajetórias dos membros da classe senhorial: primeira comunhão, formatura e casamento. É interessante de se notar que, no caso das mulheres, as três ocasiões que recebem destaque são religiosas e marcam fases diferentes de suas vidas: primeira infância, puberdade e o ingresso
35. Carta de Marianna Velho deAvellar para José Maria Velho de Avellar. Corte, 14 de outubro de 1884 (Coleção Particular 2). 

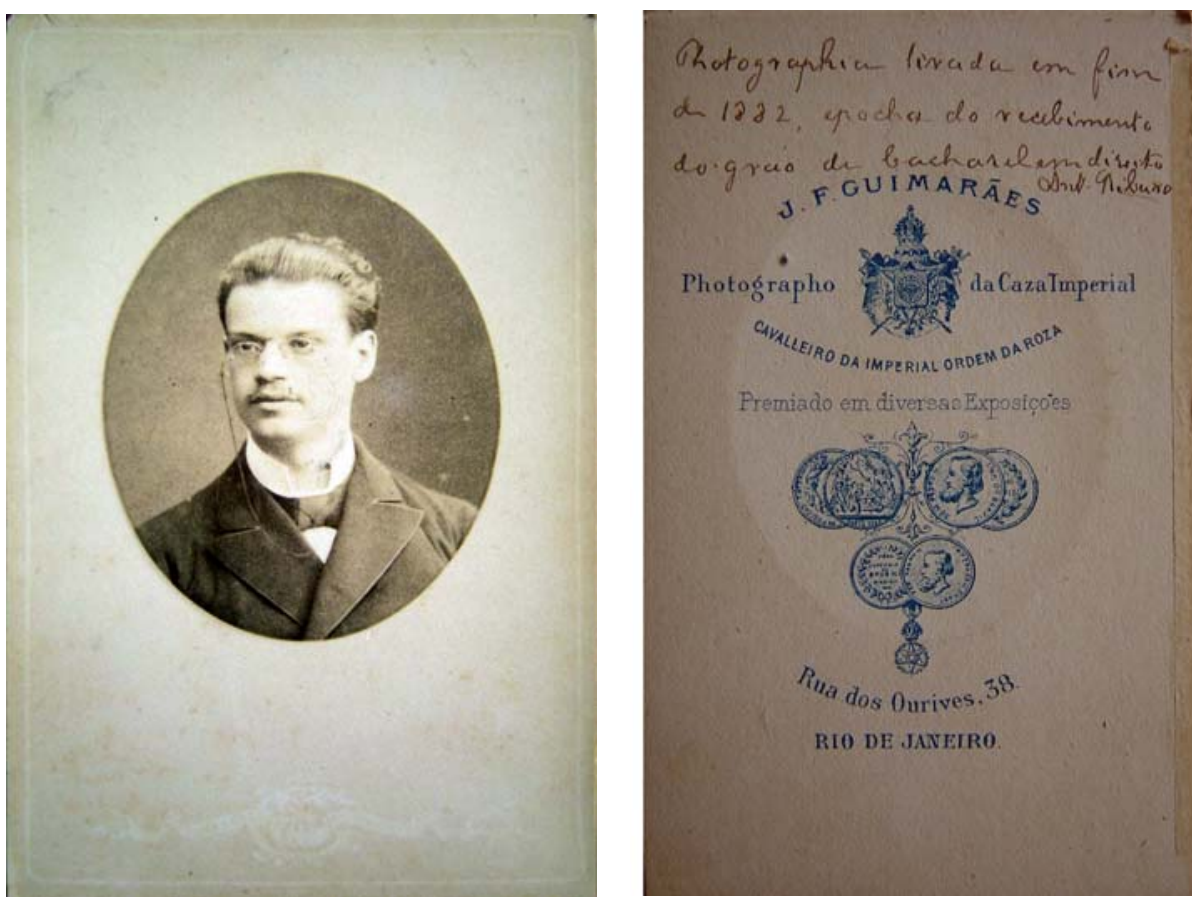

Figuras 26 e 27 - Antônio Ribeiro. J. F. Guimarães, frente e verso de carte de visite, 1882. Álbum da viscondessa de Ubá, Marianna Velho de Avellar (Álbum 1). Coleção particular 1 .

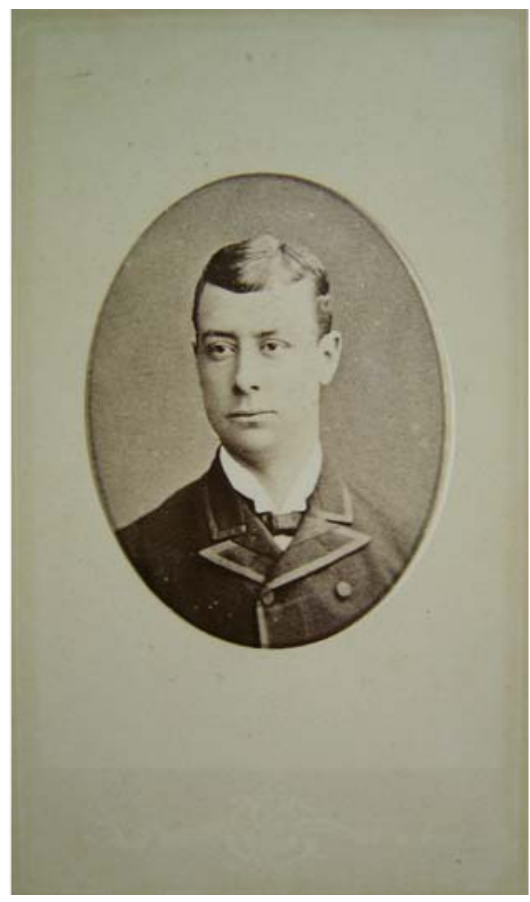

Figura 28 - José Maria. J.F.Guimarães, carte de visite, 1885. Álbum da viscondessa de Ubá, Marianna Velho de Avellar (Álbum 1). Coleção particular 1 .
36. Sobre as fases da vida no Império ver Muaze (1999; 2004).

37. Cf. Mauad (1997) na idade adulta ${ }^{36}$. No caso dos homens, a formatura cumpriria este último papel, mesmo antes do casamento. Nesse sentido, tendo sido produzidos para ressaltarem momentos individualizados, estes registros fotográficos ajudaram a tecer e reconstruir, sob novos parâmetros, um ideal de família extensa. A produção, circulação e ação desses retratos fortaleciam a família de origem, ao informar a seus pares sociais que mais um de seus membros havia cumprido pomposamente uma nova fase de vida. Assim, mantinham-se certos valores aristocráticos, ressignificados sob a égide de padrões burgueses vistos como refinados e modernos.

Nem só de caros estúdios e conceituados profissionais são compostas as imagens dos "guardados da viscondessa". Cerca de $27 \%$ das fotografias produzidas no Brasil foram tiradas pelo único fotógrafo itinerante da coleção, Manoel de Paula Ramos ${ }^{37}$. Cirurgião-dentista de profissão e fotógrafo amador, Ramos percorria as propriedades do Vale do Paraíba oferecendo seus serviços longe da concorrência das grandes cidades. Pela idade dos personagens retratados, é possível dizer que esteve na Fazenda Pau Grande pelo menos duas vezes, em 1863 e 1870. Foi responsável por 15\% do total das imagens da série estudada, sendo que esse número se eleva a $20 \%$ se forem consideradas somente as imagens de membros do grupo familiar. 
A chegada dessa figura inesperada, certamente, significava uma mudança na rotina dos habitantes da fazenda. De carroça ou no lombo de mulas, Ramos transportava um kit que constava de um fundo liso, cortinas, esteiras para o chão e aparelho de pose. Em termos de equipamento, carregava bastante volume: câmeras enormes, tripés, chapas de vidro, preparados químicos e tenda de viagem ${ }^{38}$. O mobiliário básico registrado nas fotografias pertencia às fazendas. Em alguma parte externa da residência, com boa exposição ao sol, montava-se a aparelhagem fotográfica, o cenário e o mobiliário. É interessante notar-se que toda a mise-en-scène fotográfica pertencente à cultura visual oitocentista, que tinha o estúdio fotográfico como referência, era importada para o espaço fotográfico improvisado por Ramos. $\bigcirc$ mesmo pode ser dito dos códigos de representação há muito conhecidos pelos agentes históricos em questão, bastante acostumados ao "ato de invenção de si".

Diferentemente dos renomados estúdios da Corte escolhidos pela família Ribeiro de Avellar, os serviços de Ramos podiam ser conseguidos por preços bem mais módicos. Era uma ótima oportunidade para todos os membros da família deixarem-se registrar em diferentes posições e composições de grupo. O casal Avellar apresentou-se diante da lente de Manoel de Paula Ramos usando vestimentas que buscavam dar um ar cotidiano, no entanto refinado, à imagem. Os dois dividiram a centralidade da foto, contudo o primeiro plano ficou para Joaquim, que apareceu sentado. Marianna repousava as mãos em seu ombro, em sinal de companheirismo e obediência, condizente com a representação de esposa dedicada, vigente na sociedade oitocentista. A seguir, com a mesma indumentária, também sentada, em primeiro plano, pousou cercada de livros, fazendo uma menção à ilustração e à instrução, completando a outra face do ideal feminino (Figuras 29 e 30).

Na mesma ocasião, também foi realizada a única imagem de toda a coleção em que o grupo familiar estudado aparece reunido. Para essa foto, pousaram: o Sr. e a Sra. Ribeiro de Avellar, José Maria, Júlia, Luiza e Antônio Ribeiro, todos filhos do casal (Figura 31 ).

Nesta imagem não estavam a caçula Elisa (na ocasião, com três anos) e a primogênita Mariquinhas (que morava na Corte com o marido). As outras filhas, Júlia e Luiza, usaram roupas que faziam um composée entre elas. A pose é um verdadeiro símbolo da fotografia oitocentista. Seu estudo e artificialidade conduziam a negociação entre o retratista e os retratados. Joaquim Ribeiro de Avellar comandou a cena, sentado confortavelmente numa cadeira, colocou-se em primeiro plano no espaço da figuração, personagem central no conjunto registrado. Ao seu lado, os filhos foram equilibradamente dispostos: um casal à direita e outro à esquerda. O terceiro plano foi ocupado por Marianna Velho de Avellar, exatamente atrás do marido. A pose em que Marianna e Joaquim se deixaram representar foi bastante semelhante àquela da foto onde aparecem juntos e sozinhos, dando, inclusive, a sensação de terem sido tiradas uma em seguida da outra.

Em ambos os casos, os lugares ocupados no espaço da figuração pelos agentes históricos em questão reproduziam e legitimavam uma hierarquia
38. Segundo Maria Inês Turazzi este extenso volume de equipamento perdurou até, pelo menos, a década de 1880 (TURAZZI, 1995, p. 77). 


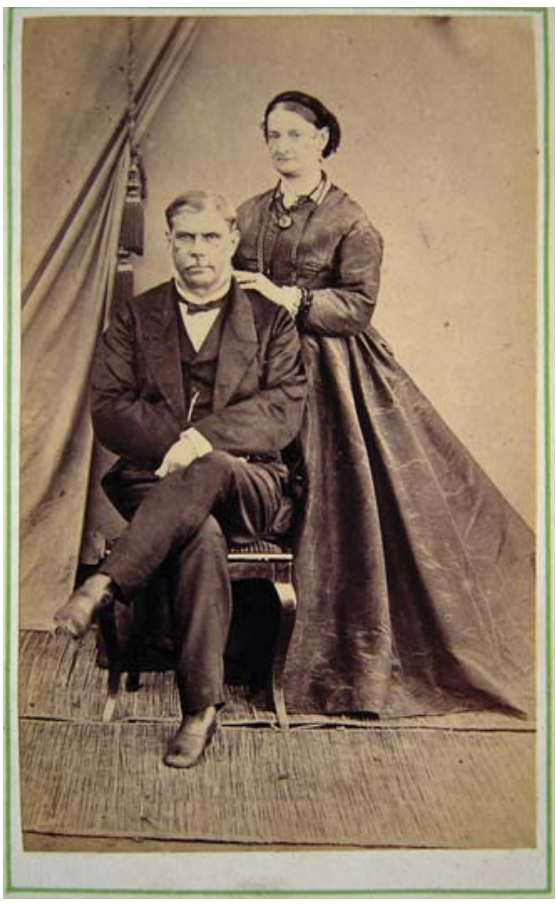

Figura 29 - Sr.e Sra. Ribeiro de Avellar. Manoel de Paula Ramos, carte de visite, 1870. Coleção de Roberto Menezes de Moraes.

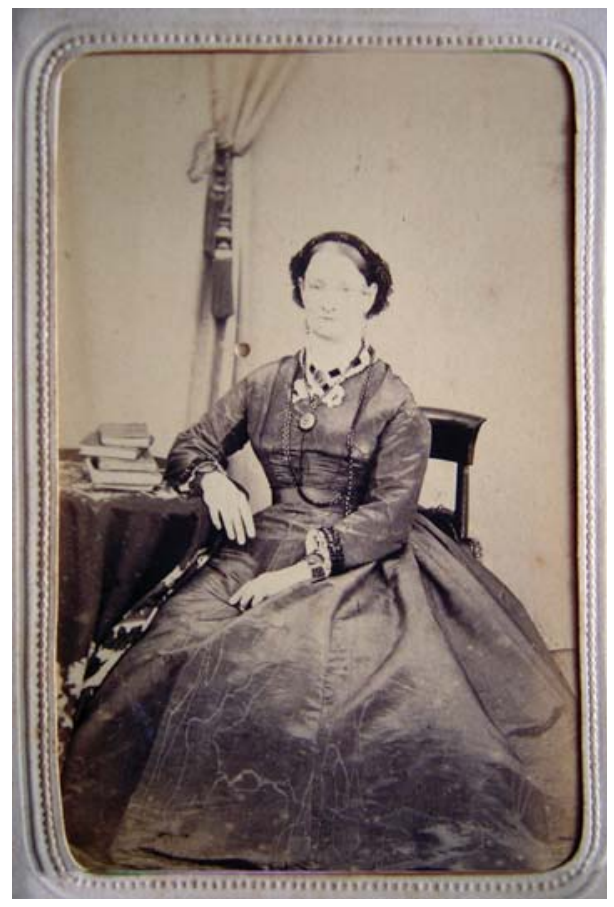

Figura 30 - Marianna Velho de Avellar. Manoel de Paula Ramos, carte de visite, 1870. Coleção de Roberto Menezes de Moraes.

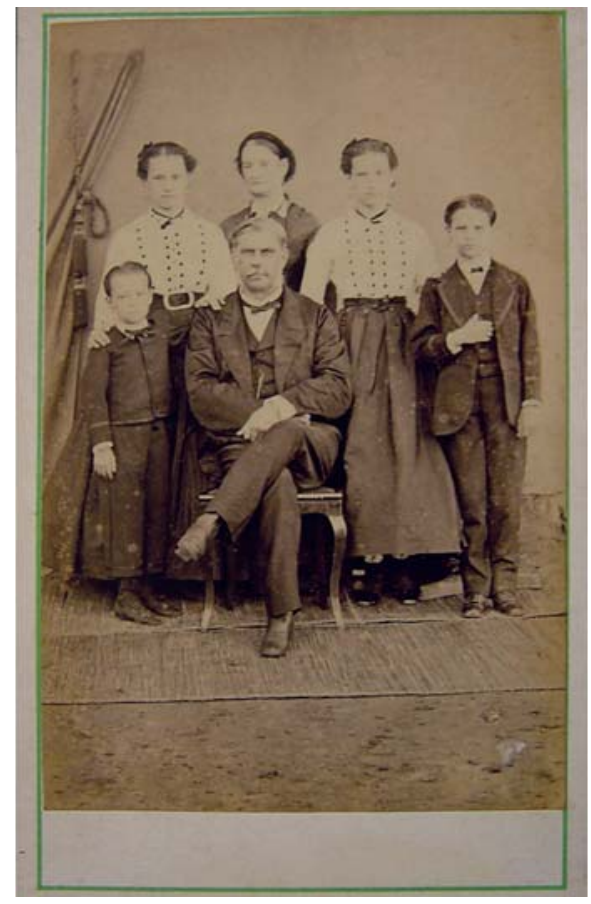

Figura 31 - Grupo Familiar Ribeiro de Avellar. Manoel de Paula Ramos, carte de visite, 1870. Coleção de Roberto Menezes de Moraes.
39. No caso das fotografias tiradas em estúdios nacionais, o índice de ovais e bustos foi de 63\% para homens e $14 \%$ para mulheres vivenciada no interior do núcleo familiar. $\bigcirc$ pai, elevado à autoridade máxima, aparecia em primeiro plano. A mão de José Maria, colocada em seu ombro, denotava respeito, admiração e confiança do filho para com ele. A viscondessa, ao fundo, era a única que tinha visão total de todos os personagens, assim como deveria proceder uma boa esposa e mãe no espaço doméstico da intimidade familiar. Esta imagem mantém um padrão que pode ser percebido em todas as fotografias tiradas por Ramos. Prevalece o enquadramento de corpo inteiro em $88 \%$ das imagens. Os $12 \%$ restantes foram de $3 / 4$ de corpo; portanto, nenhuma fotografia de busto ou oval, bastante comum na época, foi executada ${ }^{39}$. Outro traço interessante de ser ressaltado é que, em quase 100\% de seus retratos, os personagens olharam diretamente para a câmera.

Elisa, filha mais nova do casal, não figurou entre os retratados antes analisados (Figura 32). Todavia, teve sua imagem perpetuada no papel emulsionado aos três anos, como figura central da foto, no que certamente foi um de seus primeiros registros fotográficos. Mesmo estando ainda na primeira infância, Elisa foi vestida com sua melhor roupa. Como ocorreu com os outros irmãos, foram tomados todos os cuidados com a representação. Enfeitaram-na com colar, brincos de argola, e laços de fita nos punhos. Seu vestido mais curto, conforme era requisitado para sua idade, deixava aparente o aparelho de pose 
que servia como aparador para o corpo e a cabeça, evitando movimentos repentinos que pudessem tremer a imagem. Esse "descuido" foi cometido em quase todas as outras imagens infantis, onde o retratado aparece de pé e parecia ser permitido pela própria atmosfera mais descontraída da fotografia itinerante. Longe da pompa e profissionalismo dos melhores estúdios com os quais estavam acostumados, mantinha-se uma mise en scène fotográfica. Mas a precariedade de recursos do cenário parecia não importar: esteiras no chão e cortinas improvisadas, com bainhas rasgadas. Nesse caso, a oportunidade e a vontade de se deixar fotografar falavam mais forte.

Lembrando a disposição escolhida nos estúdios da Corte, mais uma vez os irmãos se retrataram juntos, em pares: Luiza com José Maria e Júlia com Antônio Ribeiro (Figuras 33 e 34). As poses escolhidas denotavam uma semelhança proposital entre as imagens, o que identificava seus personagens como de igual importância dentro do grupo familiar. As meninas, mais velhas, ocupavam o plano superior do espaço da figuração, com vestimentas iguais, que estabeleciam uma conexão entre elas. Os meninos, cada um com uma roupa condizente com sua idade, dispunham-se, sentados, no plano inferior do espaço da figuração. Mais uma vez, as fotografias comunicavam-se através de um

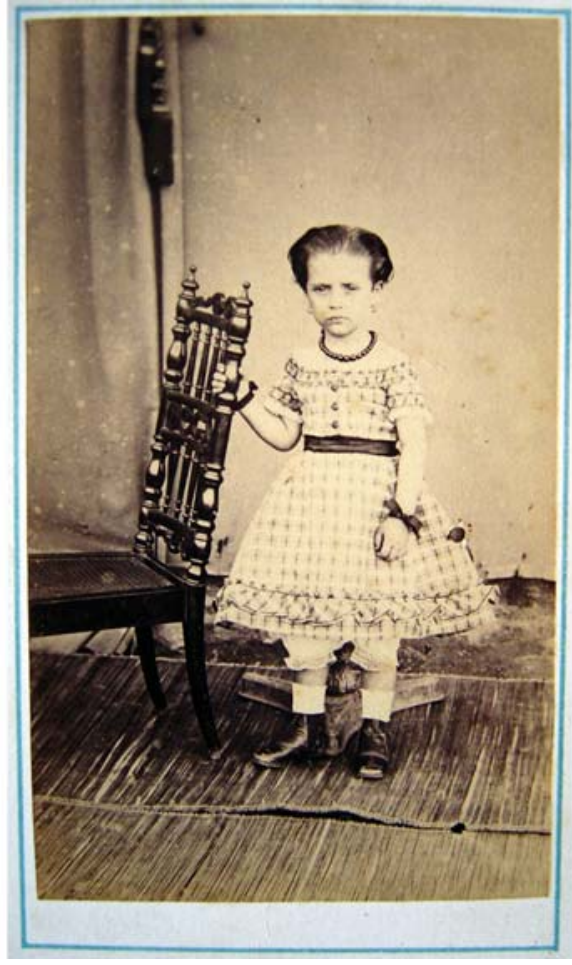

Figura 32 - Elisa Velho de Avellar. Manoel de Paula Ramos, carte de visite, 1870. Coleção de Roberto Menezes de Moraes.

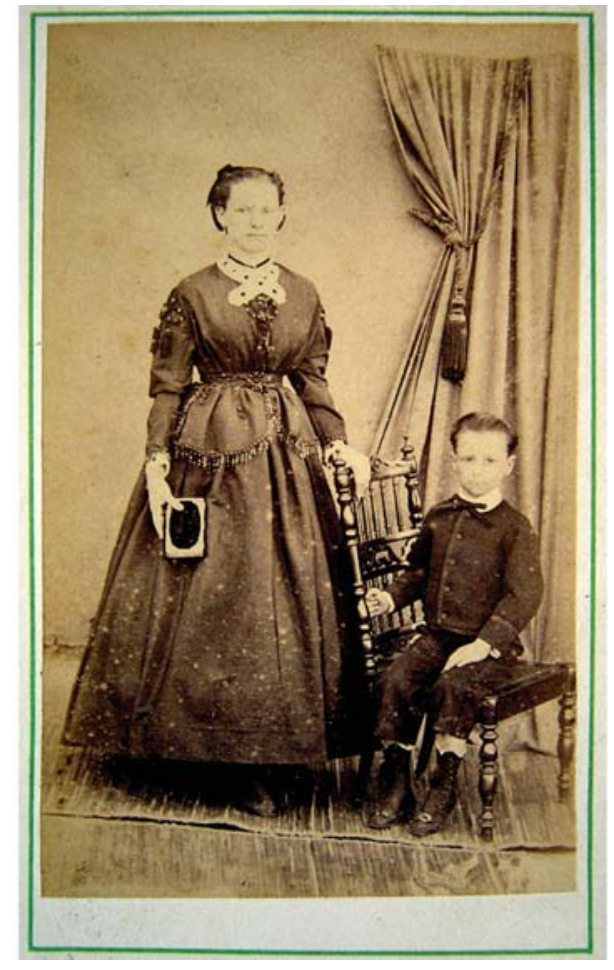

Figura 33 - Luiza e José Maria. Manoel de Paula Ramos, carte de visite, 1870. Coleção de Roberto Menezes de Moraes.

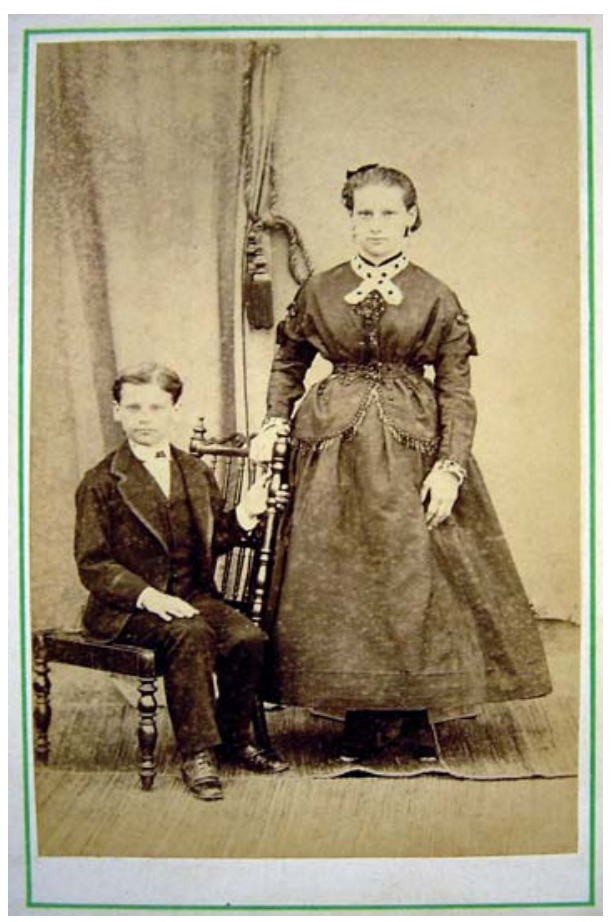

Figura 34 - Júlia e Antônio. Manoel de Paula Ramos, carte de visite, 1870. Coleção de Roberto Menezes de Moraes. 
padrão de representação que pode ser percebido. Assim, como na foto de seus pais, o plano inferior foi ocupado pelo gênero masculino e o superior pelo feminino. Tal disposição visual era mais comum nas fotografias de casal. As mulheres deviam obediência ao pai, ao marido e, no caso de falecimento dos dois primeiros, aos irmãos. Portanto, os lugares a serem ocupados (dentro e fora do grupo familiar) eram reproduzidos e legitimados pela experiência visual oitocentista que, ao receber a visita de algum fotógrafo itinerante, não se descuidava das hierarquias nem no âmbito doméstico.

O conjunto fotográfico realizado por Ramos contém determinados tipos de imagens que não haviam sido realizados em nenhuma outra situação. Foram os únicos registros encontrados do casal Marianna e Joaquim, assim como do grupo familiar quase completo. Mesmo assim, apesar da intimidade e convivência entre pais, filhos e irmãos, características do relato epistolar, as fotografias silenciavam tais teias de relacionamento e afetividade, em prol da manutenção de um padrão de visualidade a ser reproduzido no espaço de figuração da foło. Falava mais alto o habitus vivenciado no interior da classe senhorial, onde as preocupações com representação eram essenciais para a manutenção do próprio grupo familiar em determinada escala social. Optou-se pela constituição de uma dada memória familiar que seguisse os padrões da cultura visual oitocentista. Ou, talvez por estarem tão imersos nela, melhor seria dizer que não se vislumbrava nenhuma possibilidade de que fosse de outra forma.

Por tudo o que já foi dito, é possível inferir que os Ribeiro de Avellar privilegiaram dois tipos principais de circulação para seus retratos. Aqueles produzidos pelo fotógrafo itinerante Manuel de Paula Ramos tinham um circuito mais restrito. Sua distribuição ficava circunscrita aos mais íntimos e à esfera familiar. Neles havia o privilégio do registro de duas ou mais pessoas no mesmo espaço da figuração. Assim, mesmo aqueles que não freqüentavam assiduamente a Corte, tinham oportunidade de se deixar fotografar, com a vantagem de não pagarem muito por isso. Já os retratos de estúdio apresentavam um espectro de maior alcance e pompa, sendo enviados, inclusive, para amigos na Europa e usados para consolidar laços importantes como articulações de casamento, a exemplo do casamento da caçula Elisa, como foi analisado aqui. Nas imagens desses profissionais renomados, o que preponderava eram os registros individualizados.

No que se refere às idades dos sujeitos retratados individualmente, os jovens e adultos são os mais numerosos da coleção, respondendo por $71 \%$ do total. Sua aceitação e representação no meio social justificavam o maior investimento de capital simbólico feito pelas melhores famílias do Império. Em segundo lugar, vêm as imagens de crianças até 14 anos, com 15\%, e as de idosos, com $14 \%$. Entretanto, se, por um lado, quando se analisam os registros visuais individuais, as imagens infantis estão em um número reduzido, por outro, sua freqüência aumenta bastante, num universo global que inclua as fotos com duas ou mais pessoas, mesmo as de estúdio. Neste sentido, percebe-se que registros de crianças foram crescendo em profusão e investimento, acompanhando 
um processo de valorização da infância no interior da estrutura familiar, em voga na segunda metade do oitocentos. Esta "descoberta da infância" abre espaço para as crianças serem fotografadas cada vez mais cedo e, até mesmo, sozinhas ${ }^{40}$ (Figura 35). Entretanto, em muitos casos, elas ainda compartilhavam o espaço da figuração com parentes ou outras crianças (Figura 36).

Uma análise cronológica dos retratos da chamada primeira infância (idade compreendida entre o nascimento e os três anos de idade) aponta que, com o passar do tempo, as crianças foram sendo retratadas cada vez mais novas. Até que, nas décadas de 1880 e 1890, tornou-se bastante comum aparecerem individualmente, ainda bebês, com cerca de quatro meses. Como no carte de visite de Jerônimo Figueira de Mello, neto da viscondessa, tirado em 1881 para a comemoração de seu batismo (Figura 37). Tal representação infantil individualizada era impensada nos anos de sessenta, onde a idade mínima encontrada foi superior a um ano. Abaixo dessa faixa etária, os bebês eram registrados no colo de suas mães e avós. Nestes casos, seus posicionamentos no espaço da figuração estavam muito mais ligados à representação da maternidade do que à expressão individualizada.

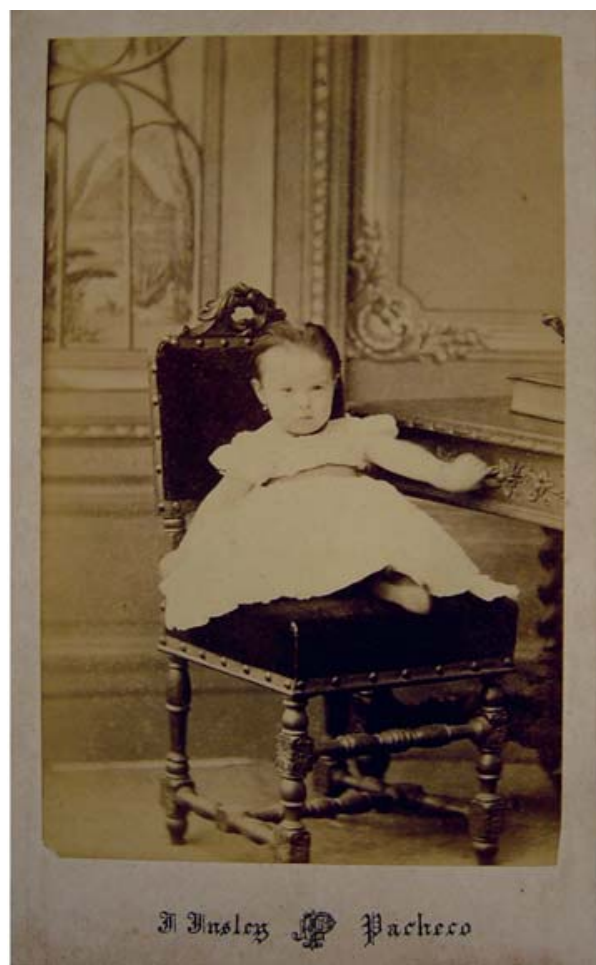

Figura 35 - Elisa. Insley Pacheco, carte de visite, 1869. Coleção de Roberto Menezes de Moraes.

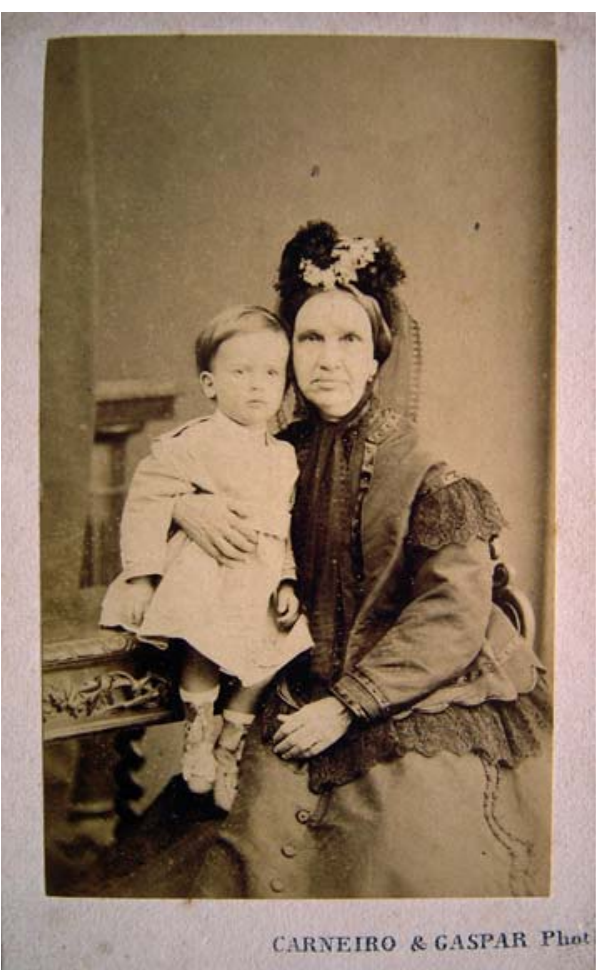

Figura 36 - Não identificados. Carneiro \& Gaspar, carte de visite, 1866/1870. Coleção de Roberto Menezes de Moraes.

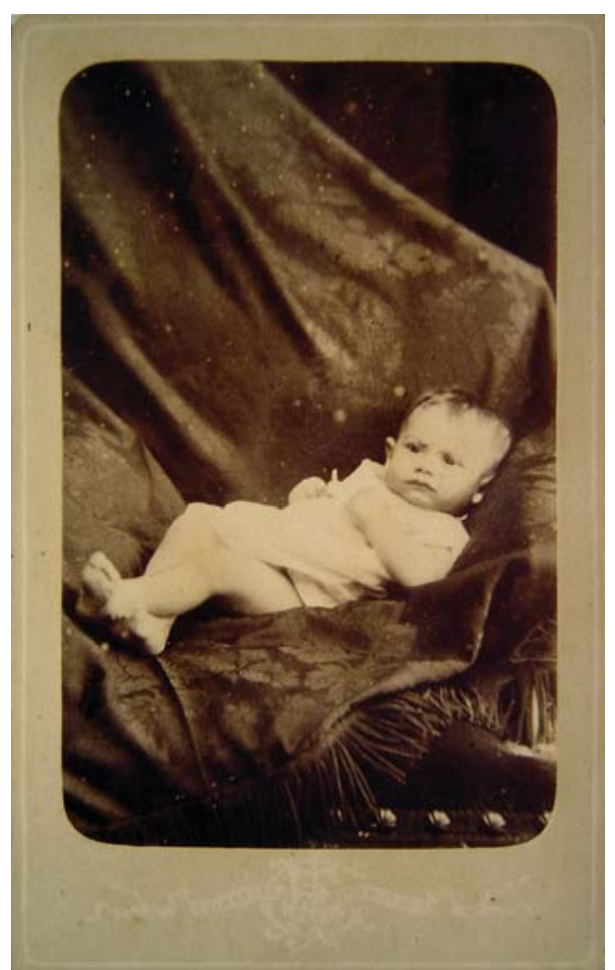

Figura 37 - Jerônimo F. de Mello. J. F. Guimarães, carte de visite, 1881. Coleção de Roberto Menezes de Moraes. 

E todas as fotografias de idosos reconhecidas são de membros do grupo familiar, com exceção dos retratos dos Imperiais, ou de pessoas que partilhavam um grau de intimidade, comprovado nas cartas pesquisadas ${ }^{41}$. Vale a pena lembrar que, por vezes, a identificação de fotografia de idosos é uma tarefa bastante abstrata. Primeiramente, a maioria das fotografias não traz, em seu verso, o ano em que foi tirada, a identificação do retratado ou mesmo sua idade. A indumentária, não muito diversa entre a fase adulta e a terceira idade, dificulta o reconhecimento dos considerados idosos. As maiores pistas ficavam a critério dos efeitos do tempo sobre o corpo dos indivíduos (Figuras 38 e 39).

A estética das imagens de idosos não se diferenciava daquela instituída para outros retratos de adultos. As fotos, na sua maioria, são todas verticais e em formato carte de visite. Há, na sua forma, uma busca do equilíbrio entre a direção esquerda e a direita, sempre tendendo a uma centralidade que trazia uma certa harmonia ao espaço e colocava o sujeito (ou os sujeitos) em posição privilegiada. No caso das fotografias com duas ou mais pessoas, a figura masculina sempre adquiria importância central, reproduzindo a lógica de

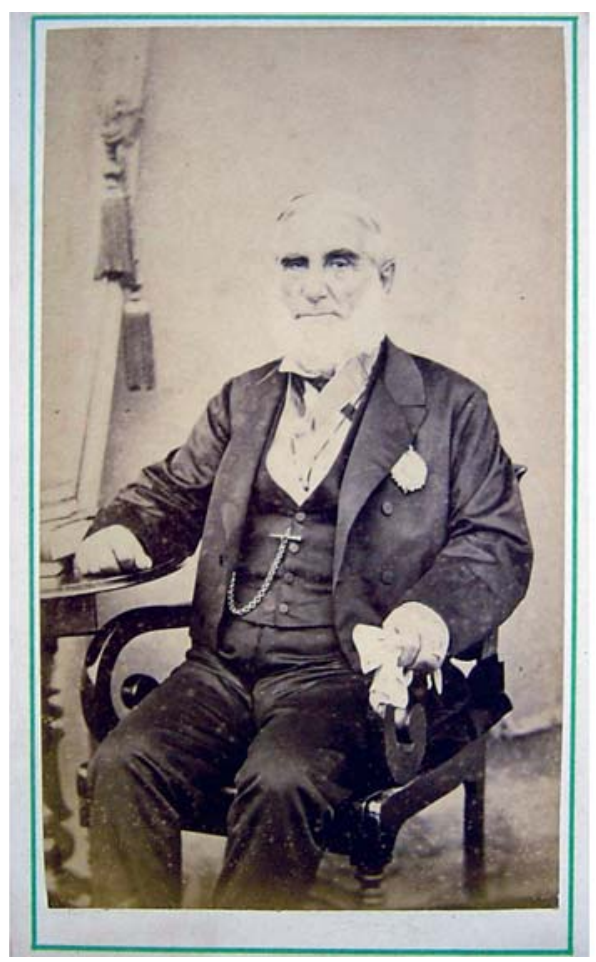

Figura 38 - Barão de Capivary. Manoel de Paula Ramos, carte de visite, 1863. Coleção de Roberto Menezes de Moraes.

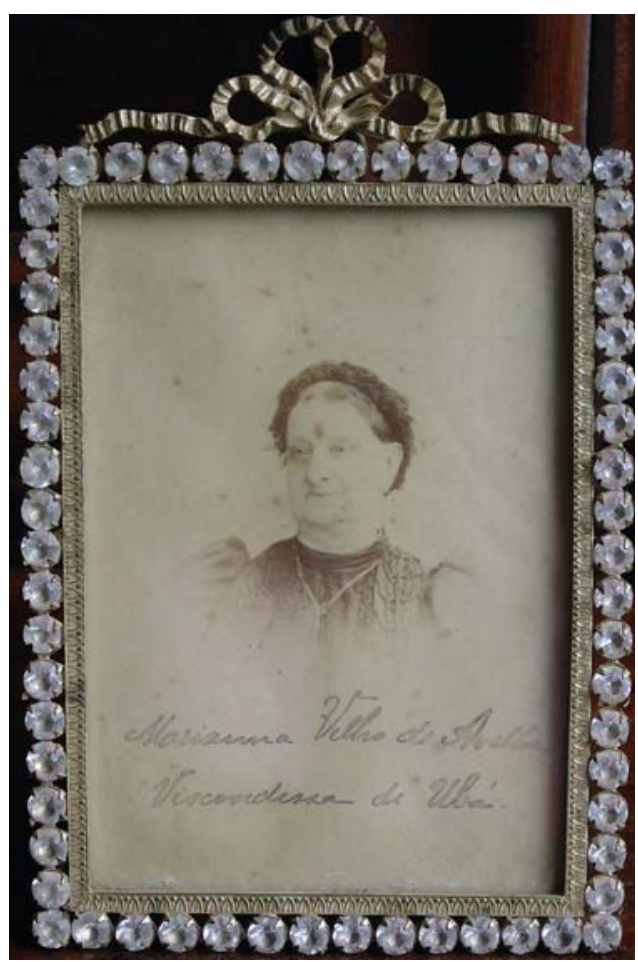

Figura 39 - Viscondessa de Ubá. Fotógrafo não identificado, 1887/1890. Álbum da viscondessa de Ubá, Marianna Velho de Avellar (Álbum 11.Coleção particular 1. 
funcionamento do sistema familiar e social da sociedade oitocentista. $\bigcirc$ mesmo ocorria com as pessoas mais velhas, sempre com papel de destaque nas fotografias; seja do marido com a esposa, da avó com o neto, de irmãos etc. Esta conclusão me faz lembrar a análise de Gilberto Freyre, para quem, nas sociedades patriarcais, o prestígio da idade avançada era grande, devido à legislação que instituía o patriarca como absoluto na administração da justiça e dos bens de família ${ }^{42}$.

No tocante à circulação, a troca de retratos parece ser uma prática em todas as fases da vida, incluindo a velhice. Entretanto, o que a sobrevivência dessas fotos sugere é que o registro da ancianidade, sua imagem revelada no papel, tinha uma distribuição bem restrita, voltada somente aos mais íntimos, pois não foram encontradas fotografias de pessoas de fora do núcleo familiar central, ou do circuito de compadres e parentes, como ocorreu em registros fotográficos de outras fases da vida. Contudo, ao pousar para a foto, as mazelas da idade, por diversas vezes descritas nas correspondências íntimas, eram esquecidas em prol da construção de uma imagem sóbria e austera de velhice. Numa elite que valorizava o poder do patriarca - em torno do qual se organizavam a honra da família, sua fortuna e patrimônio -, a velhice era respeitada e trazia a expectativa da manutenção da união familiar após a morte.

Por entre memórias e histórias

No século XIX, a sociedade européia e a brasileira (de forma periférica) vivenciaram, cada uma a seu tempo e maneira, um conjunto de transformações ligadas ao modelo capitalista de produção. Nesta nova configuração, a concepção individualista do mundo foi introduzida de forma definitiva ${ }^{43}$. O sujeito moderno viu-se cada vez mais desvinculado de coletivos que, anteriormente, o identificavam, tais como clã e família. No capitalismo, são os homens enquanto indivíduos que produzem os bens, relacionam-se entre si e constituem sociedades. O indivíduo torna-se o ponto de partida e a sociedade passa a ser vista como seu conjunto ${ }^{44}$. Nesse contexto, a invenção da fotografia, em fins da década de 1830, também pode ser entendida como resposta à necessidade do homem de dar expressão à sua individualidade num mundo em transformação ${ }^{45}$. Contudo, se no Velho Continente a fotografia esteve ligada à ascensão da sociedade burguesa e à consolidação de um modelo econômico capitalista, por excelência, no Brasil essa realidade não se verificou. No Império tropical, as relações capitalistas de produção estavam longe de se legitimarem, pois sua aplicação ao mundo do trabalho era cerceada, entre outras coisas, por um mercado consumidor restrito, respaldado por uma economia cafeeira monocultora, voltada para a exportação e movida pela mão-de-obra cativa negra.

O Estado Imperial valorizou elementos ligados à modernidade burguesa européia, tais como moda, fotografia, diversão, decoração, educação universitária, disponibilizando-os às famílias endinheiradas, sem abrir mão de
42. Ver Freyre (1996)

43. O ingresso na modernidade desperta uma gramática de novos sentimentos. Tal experiência foi amplamente narrada pela literatura oitocentista.Vários escritores descreveram a multidão nas grandes metrópoles do século XIX. Baudelaire em Paris, Edgard Alan Poe, Dickens e Engels em Londres, todos recorrentemente se dispuseram a relatar a vivência do flâneur, onde, já transformado em indivíduo, o homem se mistura na imensa massa de passantes, experimentando, assim, ao mesmo tempo, inúmeras sensações (liberdade prazer,pavor, diluição) de pertencimento e não pertencimento a um coletivo (BENJAMIN, 1989a; 1989b). Sobre o indivíduo moderno, ver também Berman (1995).

44. Cf. Norbert Elias (1994).

45. Price e Well se inspiram na definição de cultura de Raymond Williams para defender que não existe nada na tecnologia em si mesma que determine o seu uso ou lugar cultural; estes serão gerados na prática social. Ou seja, as novas tecnologias são produzidas dentro das relações de produção e consumo estabelecidas, contribuindo para articular - e, não, provocar - mudanças nas relações e nos padrões de comportamento (PRICE; WELL, 2000, p. 13). 
46. Ver Fabris (1998)

47.A escrita de si integra um conjunto de modalidades a que convencionou chamar produção de si no mundo moderno ocidental."Através desses tipos de práticas culturais, o indivíduo moderno está construindo uma identidade para si através de seus documentos, $\mathrm{cu}$ jo sentido passa a ser alargado." [...] A chave para seu entendimento é, portanto, a emergência histórica desse indivíduo nas sociedades ocidentais." (GOMES, 2004, p. 11). Apesar de o retrato fotográfico não ser calcado em uma instância verbal, proponho que ele seja considerado uma modalidade de "escrita de si”, porque possui um forte referencial autobiográfico, um caráter de construção de certa imagem escolhida e calculada para ser eternizada.

48. Cf. Lima (1995).

49. Ver Arcaísmo como Projeto (FRAGOSO; FIORENTINO, 2001). um projeto político-econômico escravista e agrário-exportador. No caso específico da imagem fotográfica, desde o princípio esta se fundou como uma "imagem de consumo", envolvida num circuito comercial ditado pela lógica do mercado que, rapidamente, foi integrado ao cotidiano familiar da elite imperial ${ }^{46}$. Seu principal consumidor foi o "homem moderno" na sua incessante busca por identidades. Neste sentido, a fotografia torna-se, também, uma forma de "escrita de si", que, assim como a correspondência íntima, permitia a elaboração de memórias e identidades, tanto individuais, quanto coletivas ${ }^{47}$. Na esfera doméstica, o retrato fotográfico alcançou grande circulação e consumo entre as famílias mais abastadas do Império. Apesar da valorização do indivíduo no seu espaço da figuração, como mostrou este artigo, não se pode concluir que houve uma completa incorporação de um modo de vida burguês em família.

No caso brasileiro, pode-se dizer que o modo de vida burguês antecedeu a implantação de uma estrutura produtiva condizente com os novos parâmetros. Ou seja, o consumo de bens materiais e certos valores ligados à esfera doméstico-familiar acabaram por organizar novas práticas e representações sociais, inspiradas numa estrutura burguesa ${ }^{48}$. Porém, como vimos nos álbuns e pertences da viscondessa de Ubá, a absorção de um novo habitus social ocorria em constante diálogo com ideais tradicionais, como os atrelados ao cânone da família extensa. A privacidade e a vida familiar oitocentista nasceram dessa ressignificação de valores aristocráticos e modernos; burgueses e escravocratas. Contudo, no Império tropical, isso não representava nenhum antagonismo ou contradição. A leitura cruzada das imagens fotográficas com o espaço fora da foto (cartas, diários e outros documentos escritos) revela que justamente a riqueza gerada no mundo da escravidão - com o plantio de café e os empréstimos a juros - possibilitava às famílias aristocráticas um tipo de representação diferenciada, com o consumo de fotografia e de outras mercadorias burguesas.

Entretanto, não se tratava do desfrute puro e simples de outras mercadorias, mas da incorporação de um novo habitus social. Desta forma, percebe-se que os circuitos de ingresso na civilização burguesa ocidental não vêm necessariamente acompanhados pela efetiva implantação de uma cultura burguesa na sua dimensão mais totalizante de modo de vida. Ou seja, a classe senhorial oitocentista implementou práticas de consumo ligadas ao modo de vida burguês, mas sem deixar de desfrutar dos benefícios materiais que, acreditava, a estrutura escravista existente the proporcionava. Nesse sentido, a viscondessa de Ubá se apresenta na intercessão entre a modernidade burguesa e o arcaísmo escravista ${ }^{49}$. Uma personagem feminina que vivenciou, de forma consciente ou inconsciente, dois mundos complementares, aparentemente antagônicos, porém conciliáveis. Assim, soube executar com maestria o governo da casa e a maternidade, funções primordiais da mulher oitocentista, contando para isso com o respaldo econômico gerado na lavoura cafeeira do Pau Grande. Ao mesmo tempo, investia nos melhores estúdios, modistas e professores; freqüentava a boa sociedade; colecionava e organizava fotografias nos álbuns de família como os aqui analisados. 


\section{REFERÊNCIAS}

FONTES

Arquivo Nacional

Auto de casamento de Manoel Vieira Tosta e D. Maria José Velho de Avellar.Arquivo Nacional, Fundo Família Vieira Tosta, QE, Seção de Guarda SDP, Instrumento SDP 019, caixa 2, documento 1.

Coleção de Roberto Menezes de Moraes (fotografias avulsas).

Coleção Particular 1 (três álbuns de fotografias e documentos).

Coleção Particular 2 (quatro séries epistolares).

Carta de D. Leonarda Maria Velho da Silva para Marianna Velho de Avellar. Glória, 4 de março de 1854. (Coleção Particular 2).

Carta de Leonarda Maria Velho da Silva para Marianna Velho de Avellar. Rio, 27 de maio de 1854. (Coleção Particular 2)

Carta de José Maria da Silva Velho para sua irmã, Marianna Velho deAvellar. Catete, 4 de dezembro de 1855. (Coleção Particular 2).

Carta de Marianna Velho de Avellar para D. Leonarda Velho da Silva, Pau Grande, 11 de julho de 1864. (Coleção Particular 2).

Carta de Leonarda Maria Velho da Silva para Marianna Velho de Avellar. Petrópolis 12 de agosto de 1866. (Coleção Particular 2)

Carta de D. Leonarda Velho da Silva para Marianna Velho de Avellar. Rio de Janeiro, 30 de março de 1867. (Coleção Particular 2).

Carta de José Maria Velho da Silva para Marianna Velho de Avellar. Petrópolis, Quarta- feira, 13 de dezembro 1867. (Coleção Particular 2).

Carta de Elisa Velho de Avellar para José Maria Velho de Avellar. Rio, 5 de setembro de 1884. (Coleção Particular 2).

Carta de Marianna Velho de Avellar para José Maria Velho de Avellar. Corte, 8 de setembro de 1884. (Coleção Particular 2)

Carta de Marianna Velho de Avellar para José Maria Velho de Avellar. Corte, 6 de outubro de 1884. (Coleção Particular 2).

Carta de Marianna Velho de Avellar para José Maria Velho de Avellar. Corte, 14 de outubro de 1884. (Coleção Particular 2).

\section{BIBLIOGRAFIA}

BENJAMIN, Walter. O flâneur. In: Obras escolbidas III: Charles Baudelaire, um lírico no auge do capitalismo. São Paulo: Brasiliense, 1989a. 
. Sobre alguns temas em Baudelaire. In: BENJAMIN, Walter. Obras escolbidas III: Charles Baudelaire, um lírico no auge do capitalismo. São Paulo: Brasiliense, 1989b.

BERMAN, Marshall. Tudo que é sólido desmancha no ar: a aventura da modernidade. São Paulo: Companhia das Letras, 1995.

CARNEIRO,Vânia; LIMA, Solange Ferraz de. Fotografia como objeto de coleção e de conhecimento: por uma relação solidária entre pesquisa e sistema documental. In: MAUAD, Ana Maria (Org.). Anais do Museu Histórico Nacional. Rio de Janeiro, v. 32, p. 15-35, 2000.

ELIAS, Norbert. O processo civilizador. v. II: Formação do Estado e civilização. São Paulo: Jorge Zahar, 1993.

O processo civilizador.v. I: Uma história de Costumes. São Paulo: Jorge Zahar, $1994 a$. A sociedade dos indivíduos. Rio de Haneiro: Jorge Zahar, 1994b.

.A sociedade de corte. $2^{\mathrm{a}}$ ed.Trad.Ana Maria Alves. Lisboa: Estampa, 1995.

ELIAS, Norbert; SCOTSON, John L. The stablished and the outsiders: a sociological enquiry into community problems. London: Sage, 1994.

FABRIS, Annateresa.A invenção da fotografia: repercussões sociais. In: Fotografia: usos e funções no século XIX. São Paulo: Edusp, 1998, p. 11-37.

FRAGOSO,J.;FLORENTINO, M. Arcaísmo como projeto. $4^{\mathrm{a}}$ ed. Rio de Janeiro: Civilização Brasileira, 2001.

FREYRE, Gilberto. Casa grande e senzala. 25ª ed. São Paulo:José Olympio, 1987.

Sobrados e mucambos. $9^{\text {a }}$ ed. São Paulo: Record, 1996.

GOMES,A. de Castro. Escrita de si, escrita da história: a título de prólogo In: (Org.). Escrita de si, escrita da bistória. Rio de Janeiro: Fundação Getúlio Vargas, 2004, p. 7-24.

LE GOFF, Jacques. Documento/monumento. In: Enciclopédia Einaudi. v. I. Lisboa: Imprensa Nacional-Casa da Moeda, 1985, p. 11-51.

LIMA, Tania Andrade. Pratos e mais pratos: louças domésticas, divisões culturais e limites sociais no Rio de Janeiro, século XIX. Anais do Museu Paulista: História e Cultura Material. São Paulo, v. 3, p. 129-191, jan.-dez. 1995 (Nova Série).

MAUAD, Ana Maria. Resgate de memórias. In: CASTRO, H.; SCHNOOR, E. Resgate: uma janela para o oitocentos. Rio de Janeiro:Topbooks, 1995, p. 99-138.

.Através da imagem: fotografia e história, interfaces. In: Tempo, Niterói, v.1, n. 2, p. 73-98, 1996 (Universidade Federal Fluminense-Departamento de História; Rio de Janeiro: RelumeDumará). 
. Imagem e auto-imagem do Segundo Reinado. In:ALENCASTRO, Luiz Felipe de (Org.). História da vida privada no Brasil. v. II. São Paulo: Companhia das Letras, 1997, p. 181-232.

Entre retratos e paisagens: as imagens do Brasil oitocentista. In: MARCONDES, Neide; BELLOTO, Manoel (Org.). Turbulência cultural em cenários de transição: século XIX iberoamericano. São Paulo: Edusp, 2005, p. 13-49.

MUAZE, Mariana de A. F. A Descoberta da infância: a construção de um habitus civilizado na boa sociedade imperial. Dissertação (Mestrado em História)-Departamento de História, Pontifícia Universidade Católica, Rio de Janeiro, 1999.

As várias faces da velhice In: LEMOS, M.T.; ZABAGLIA, R.(Org.) A arte de envelbecer: saúde, trabalho, afetividade, estatuto do idoso. São Paulo: Idéias \& Letras; Rio de Janeiro: Editora da Universidade Estadual do Rio de Janeiro, 2004, p. 95-116.

O império do retrato: família, riqueza e representação social no Brasil oitocentista (18401889). Tese (Doutorado em História)-Faculdade de História, Universidade Federal Fluminense, Niterói, 2006.

MENESES, Ulpiano T. Bezerra de. Fontes visuais, cultura visual, história visual: balanço provisório, propostas cautelares. Revista Brasileira de História, São Paulo, v. 23, n. 45, p. 11-36, 2003 (Anpuh/Humanitas).

PRICE, Derrick; WELL, Liz (Org.). Photography: A Critical Introduction. 2. ed. London: Routedge, 2000.

QUEIROZ, Maria Isaura Pereira de. Cultura, sociedade rural, sociedade urbana no Brasil. Rio de Janeiro: Livros Técnicos e Científicos; São Paulo: Edusp, 1978.

SOUZA, Gilda de Mello e. O espírito das roupas. 4. ${ }^{a}$ ed. São Paulo: Companhia das Letras, 2001.

TURAZZI, Maria Inês. Poses e Trejeitos: a fotografia e as exposições na era do espetáculo (18391889). Rio de Janeiro: Funarte; Rocco, 1995.

VASQUEZ, Pedro Karp. O Brasil na fotografia oitocentista. São Paulo: Metalivros, 2003.

Artigo apresentado em 9/2006. Aprovado em 11 1/2006. 